\title{
Why Did the Revolutionary Lawyers Confuse Custom and Reason?
}

\author{
James Q. Whitman†
}

Let the bar proclaim, "the laws, the rights, the generous plan of power" delivered down from remote antiquity ... . . Let them search for the foundations of British laws and government in the frame of human nature, in the constitution of the intellectual and moral world. ${ }^{1}$

John Adams (1765)

I recalled the method practiced once upon a time by $M$. Descartes to arrive at the philosophical verities he sought; and I persuaded myself that the. Jurist could do the same in order to discover the verities of Justice .... . If one were to compare the various customs [of France], one would be in a position to form a Plan of Universal Jurisprudence .... .

Louis Boullenois (1732)

It is absolutely necessary that the national constitution be reduced to evident, brief principles .... For where the constitution has not been made evident, everything simply retains the shape given it by custom, [from] pre-literate times . . . and only a couple of dozen historical-critical minds will be interested in it . ... ${ }^{3}$

Ludwig Timotheus von Spittler (1796)

$\dagger$ Assistant Professor of Law, Stanford University. B.A., Yale, 1980; M.A., Columbia, 1982; Ph.D., The University of Chicago, 1987; J.D., Yale, 1988.

Earher versions of this Article were presented to the American Society for Legal History, the Harvard Law School Legal History Series, and the Stanford Legal History Workshop. I am grateful to participants in all these groups for their comments. I would in particular hike to acknowledge helpful suggestions from Keith Baker, Paul Brest, Mauro Cappelletti, Elizabeth Fowler, Charles Gray, Thomas Grey, Brian Levack, David Lieberman, Deborah Weiss, and Harry Wellington. I am especially grateful for sharp criticism by Charles Donahue. This research was supported by The Stanford Legal Research Fund, made possible by a bequest from Ira S. Lillick and by gifts from other friends of the Stanford Law School.

1 John Adams, A Dissertation on the Canon and Feudal Law, in Charles Francis Adams, ed, 3 The Works of John Adams 447, 463 (Charles C. Little and James Brown, 1851).

1 Louis Boullenois, Dissertations sur des Questions qui Naissent de la Contrariété des Loix et des Coutumes xiv, xxii (Mesnier, 1732).

3 Ludwig T. v. Spittler, Vorlesungen uber Politik, in Karl Wächter, ed, 15 Sämmtliche Werke 130-31 (J.G. Cottaschen, 1837). On the context, see Erwin Hölzle, Das Alte Recht und die Revolution 76-84 (R. Oldenbourg, 1931). 
The first of the three passages above was written in colonial America, on the eve of the Revolution; the second, in France, on the eve of the French Enlightenment; and the third, in the Württemberg of the young Hegel. All three show the same belief, even if expressed in different words: the belief that custom could be, and indeed must be, "reduced" to principles of reason. All three display the habit B.F. Wright saw as typical only of revolutionary America: the "somewhat unclear mingling of the divine law, the law of reason, and the principles of the . . . Constitution.""

That "somewhat unclear mingling" of reason, custom, and constitution, is my subject in this Article. This Article offers a general historical account of how the constitutionalist lawyers of the eighteenth-century world came to mingle ideas of customary right with characteristically eighteenth-century ideas of deductive natural law. ${ }^{5}$ To understand this tendency to conflate custom and reason, I will suggest, we must understand developments that long predated the passages quoted above. The eighteenth-century constitutionalist habit of identifying custom with reason should be traced back to the collapse of customary proof practices at the end of the Medieval period-a collapse with a long train of institutional and ideological consequences.

In making my argument, I will range widely over both AngloAmerican and Continental legal traditions. But my principal goal is to prove two points about the legal legacy of the American Revolution. First, I want to demonstrate that the legal culture of eighteenth-century America belongs in a broad international context. The peculiar patterns of thought that characterized the American lawyers of the revolutionary era were also the peculiar patterns of thought that characterized the lawyers of continental Europe. Odd as it may sound, the same pressures and traditions that produced John Adams also, to some extent, produced Hegel.

- Benjamin Fletcher Wright, The Early History of Written Constitutions in America, in Carl Wittke, ed, Essays in History and Political Theory in Honor of Charles Howard McIlwain 341, 360 (Russell \& Russell, 1967).

- I should emphasize here that the confusion I trace is between custom and deductive natural law thought; indeed, throughout, by "natural law," I mean exclusively "deductive natural law." It is this that distinguishes the tradition I discuss here from the medieval practice of calling custom a form of "second nature." See Donald Kelley, "Second Nature": The Idea of Custom in European Law, Society, and Culture, in Anthony Grafton and Ann Blair, eds, The Transmission of Culture in Early Modern Europe 131 (Pennsylvania, 1990); Donald R. Kelley, The Human Measure: Social Thought in the Western Legal Tradition (Harvard, 1990). See also note 111 and accompanying text. 
Second, and more important, I want to raise some necessary doubts in the minds of scholars of the American Revolution, who have not quite faced the historical problems presented by the "mingling" jurisprudence of the eighteenth century. For generations, Americanists have debated whether the legal thinking of the American Revolutionaries was "about" custom or "about" deductive natural law. Legal historians once widely assumed that the Revolution was instigated, and the Constitution ratified, by lawyers who were somehow motivated by a belief in deductive natural law. ${ }^{6}$ More recently, historians have tended to suppose that common law tradition, or customary law tradition, or some mixture of the two described by the catch-phrase "Rights of Englishmen," was the motivating force. ${ }^{7}$ Both of these lines of interpretation attribute much more coherence and intelligibility to revolutionary era legal writings than those writings possess. ${ }^{8}$ Revolutionary era lawyers unreflectively conflated reason and custom-which means that, in many respects, we can never draw definitive conclusions about constitutional interpretation from their writings.

The Sections that follow will trace the roots of eighteenth-century jurisprudence in an international legal history stretching back to the Dark Ages. Section I will review the pattern of "mingling" custom and reason that characterized legal writings of the American revolutionary era. Section II will proceed to identify the historical origin of this pattern. Part A of Section II will describe a critical procedural practice in the Middle Ages: the interviewing of local witnesses to determine local custom. Part B will show how the early modern period witnessed an evidentiary crisis of custom, as increasingly centralized court systems proved unable to ascertain local custom. Part $\mathrm{C}$ will describe how Continental lawyers in the seventeenth century struggled to fill the gaps in the customary system of proof with principles of natural law and reason. As a result, Part $\mathrm{C}$ will show, the European legal literature of that period often invoked a confusing mix of "customary common law" and "reason." Part D will describe how English jurists in the seventeenth century confused reason and custom much as their Continental counterparts did.

- See text accompanying notes $25-26$.

7 See text accompanying notes 27-29.

s Even works that recognize the coexistence of these two discourses, I will argue, attribute more jurisprudential intelligibility to American legal writings than is appropriate. For such works, see note 19 and accompanying text. 
Finally, Section III will show how the evidentiary crisis of custom led to the mingling of custom and reason characteristic of the jurisprudence of the American revolutionary era. That jurisprudence was borrowed from the writings of the seventeenth century, by American lawyers who did not understand the institutional context of the ideas they repeated, and who had lost sight of the seventeenth-century concepts of reason. As a result, revolutionary era concepts such as "rights" and "constitution" lack fundamental jurisprudential intelligibility; literature that purports to explain those concepts can never be satisfactory. ${ }^{\circ}$

I should say at the outset that the interpretation I will offer will sweep very broadly over European history-more broadly than most historians would be willing to sweep, and in a more essay-like fashion. Nevertheless, I hope to win over European legal historians at least tentatively to my view. As for American legal historians and lawyers, I hope to convince them that understanding the jurisprudence of the American revolutionary requires, in the last analysis, a wide acquaintance with a great deal of western legal history.

\section{I. "Mingling" Custom and Reason in the Revolutionary Era}

When the first Continental Congress gathered in Philadelphia, wrote John Adams in his diary, "[one of t] he two points which labored the most [was w] hether we should recur to the law of nature, as well as to the British constitution, and our American charters and grants. Mr. Galloway and Mr. Duane were for excluding the law of nature. I was very strenuous for retaining and insisting on it ...." Behind this disagreement over the importance of "the law of nature" lay generations of uncertainty.

Legal thought among the American revolutionary lawyers presented a picture of apparent intellectual chaos, drawn from a variegated mass of traditions. When the Revolution began, the mental world of American lawyers was made up of a flourishing variety of inconsistent jurisprudential systems, irreconcilable assumptions, and mismatched intellectual inheritances. Ideas of natural law taken from such Enlightenment vulgarizers as Vattel and Burlamaqui ${ }^{11}$ coexisted, in colonial minds, with the subtleties of

- See note 170 and accompanying text.

10 John Adams, Diary, in 2 The Works of John Adams 1, 374 (Charles C. Little and James Brown, 1850). See the discussion of Adams in Edward Corwin, The "Higher Law" Background of American Constitutional Law, 42 Harv L Rev 365, 400-01 (1929). For the Declaration this ultimately produced, see Wright, The Early History of Written Constitutions at 360 (cited in note 4).

1 For the popularity of Burlamaqui, see Benjamin Fletcher Wright, American Interpretations of Natural Law: A Study in the History of Political Thought 8 (Russell \& Russell, 1962). For Vattel, see id at 67, 79, 129, 237. 
Montesquieu and Coke. ${ }^{12}$ If American lawyers all endorsed the common law, it is hardly clear that they all conceived of the common law in the same way, for they received widely varying training. ${ }^{13}$ If admiration for the English constitution was universal, it is unclear what shape the English constitution had in American minds. ${ }^{14}$

The apparent disorder was worst in the many writings that commingled talk of "natural law" or the "law of reason" with talk of the English constitution and customary law. Prime among such passages familiar to eighteenth-century readers was Bolingbroke's famous and influential statement:

By constitution we mean, whenever we speak with propriety and exactness, that assemblage of laws, institutions, and customs, derived from certain fixed principles of reason, directed to certain fixed objects of public good, that compose the general system, according to which the community hath agreed to be governed. ${ }^{15}$

This passage captures the apparent lack of order in Anglo-American legal writing of the eighteenth century. What did Bolingbroke mean? Why should "laws, institutions and customs" be "derived from ... fixed principles of reason" and how had any the community consented to be governed either by reason or by custom? Bolingbroke gave no answer. Neither did Blackstone, whose ability to speak simultaneously of custom and reason continues to trouble scholars. ${ }^{16}$ And neither did the American lawyers who quoted Bol-

12 For the influence of Montesquieu in America, see id at 44, 89. In Europe, DeLolme ranked alongside Montesquieu as an expositor of the British constitution, and eighteenthcentury editions of his work are quite numerous in American libraries. I do not know what influence DeLolme had in America.

${ }^{13}$ See Ermest Barker, Natural Law and the American Revolution, in Traditions of Civility: Eight Essays 263, 266-68 (Archon, 1967); David A. Lockmiller, Sir William Blackstone 169-90 (North Carolina, 1938); Dennis Nolan, Sir William Blackstone and the New American Republic: A Study of Intellectual Impact, 51 NYU L Rev 731 (1976); Julius Goebel, The Common Law and the Constitution, in W. Melville Jones, ed, Chief Justice John Marshall: A Reappraisal 101, 109 (Cornell, 1956); R. Kent Newmyer, Supreme Court Justice Joseph Story: Statesman of the Old Republic 41-43 (North Carolina, 1985).

14 See Jack P. Greene, From the Perspective of Law: Context and Legitimacy in the Origins of the American Revolution, 85 S Atlantic Q 56, 57 (1987).

${ }_{18}$ Lord Bolingbroke, A Dissertation upon Parties, in 2 The Works of Lord Bolingbroke 88 (Henry G. Bohn, 1844). For the influence of this passage, see Charles H. McIlwain, Constitutionalism, Ancient and Modern 5 (Cornell, 1940); Gordon S. Wood, The Creation of the American Republic, 1776-1787 260-61 (Norton, 1969).

16 See David Lieberman, The Province of Legislation Determined: Legal Theory in Eighteenth-Century Britain 44-45 (Cambridge, 1989). 
ingbroke and Blackstone, and who spoke in similar terms. We may well puzzle, for example, over the Massachusetts Circular Letter of 1768, which identified "the fundamental rules of the British constitution" with "an essential, unalterable right, in nature . . .."17 What sort of jurisprudence could provoke this faintly comical identification of the constitution of England with the laws of Eternity? What sort of suppositions underlay Alexander Hamilton's or Richard Bland's similar statements? ${ }^{18}$

It is, to be sure, possible to imagine sophisticated jurisprudential arguments that could make sense of these passages. In particular, one might be able to reconcile custom with reason by thinking of "reason" as "practical reason" or "wisdom." "Practical reason" of this pragmatic kind would be a body of sound principles revealed through the lived experience of custom. Indeed, a number of scholars have argued that the best of common law theory down through the ages has offered precisely this kind of sophisticated reconciliation of custom and reason. ${ }^{19}$ But the bulk of revolutionary era passages show little evidence of such a sophisticated concept of "reason." On the contrary, these writings often speak of "reason" as a body of "fixed principles," of "immutable maxims of reason and justice" to be discovered through deductive thought, not through lived experience. ${ }^{21}$ The revolutionary lawyers, far from embracing any pragmatic concept of "reason," generally embraced a deductive, post-Cartesian variety. ${ }^{22}$ And such a deductive con-

${ }_{17}$ Corwin, 42 Harv L Rev at 400 (cited in note 10) (quoting MacDonald, Doeumentary Source Book 146-50 (1768)).

18 "Bland is not content to rely upon the principles of the British Constitution alone; he interlards his dissertation upon this system hy references to the laws of nature." Wright, American Interpretations of Natural Law at 79 (cited in note 11). "[Hamilton] argues that the proper solution of the present discontents can be secured only by a study of the principle of 'natural justice' and the "fundamental principles of the Enghish Constitution.' "Id at 89.

10 See Lieberman, Province of Legislation at 44-45 (cited in note 16) (discussing Blackstone); Shannon C. Stimson, The American Revolution in the Law: Anglo-American Jurisprudence before John Marshall 79-80 (Princeton, 1990) (discussing John Adams). See also Charles Gray, Reason, Authority, and Imagination: The Jurisprudence of Sir Edward Coke, in Perez Zagorin, ed, Culture and Politics from Puritanism to the Enlightenment 25 (California, 1980); and Gerald Postema, Some Roots of our Notion of Precedent, in Laurence Goldstein, ed, Precedent in Law 9, 15-23 (Clarendon, 1987).

${ }^{20}$ For a largely unsupported argument that John Adams's writings offer a sophisticated reconciliation of custom and reason, see Stimson, The American Revolution in the Law at 79-80 (cited in note 19).

21 See Wright, American Interpretations of Natural Law at 78 (cited in note 11).

22 See generally the literature cited and discussed in the text accompanying notes 2526. 
cept of reason is very difficult to reconcile with custom. ${ }^{23}$ For the discourse of custom is inductive, a discourse of the contingent, the historical; whereas the discourse of deductive reason is a discourse of the inevitable and the timeless. The discourse of custom is a discourse of the peculiar and the local notions-of, for example, "the rights of Englishmen." The discourse of deductive reason, by contrast, is a discourse of the universal-of "the rights of Mankind."

How then could revolutionary thought mix these two discourses? Historians have made little effort to explain this confusion. On the contrary, with a very few exceptions, ${ }^{24}$ historians have hardly even acknowledged that Americans mingled custom with reason. Rather, historians have typically maintained that Americans were concerned exclusively with either the one or the other.

From the late 1920's onward to the late 1950's, historians commonly assumed that ideas of deductive natural law were the great principles that shaped legal thinking in the later eighteenth century, and that references to historic and particular rights were barely plausible efforts to give the color of law to an illegal revolution. ${ }^{25}$ By the mid-1950s, a historian such as Clinton Rossiter could

2s For various statements of the contrast between natural law and customary right, see J.G.A. Pocock, Modes of Political and Historical Time in Early Eighteenth-Century England, in Virtue, Commerce and History: Essays on Political Thought and History, Chiefly in the Eighteenth Century 91 (Cambridge, 1985); Ernst Troeltsch, The Ideas of Natural Law and Humanity in World Politics, in Otto Gierke, ed, Natural Law and the Theory of Society: 1500 to 1800201 (Beacon, 1957); Friedrich Meinecke, Die Entstehung des Historismus (R. Oldenbourg, 1936); Kelley, The Human Measure 2 (cited in note 5).

26 See Stimson, The American Revolution in the Law at 7 (cited in note 19); Wright, The Early History of Written Constitutions at 360 (cited in note 4); and Otto Vossler, Studien zur Erklärung der Menschenrechte, in Roman Schnur, ed, 11 Zur Geschichte der Erklärung der Menschenrechte: Wege der Forschung 166, 186 (Wissenschaftliche Buchgesellschaft, 1964) ("In Enghsh political and juristic literature . . . positive law, good old inherited law, or saxon law is repeatedly closely bound up with or muddled with the law of reason or natural law or divine law.").

${ }^{25}$ For important works focusing on natural law, see especially Wright, American Interpretations of Natural Law (cited in note 11); and Corwin, 42 Harv L Rev 365 (cited in note 10). The years between 1923 and 1940 saw a large body of work that took various approaches. See Charles Warren, New Light on the History of the Federal Judiciary Act of 1789, 37 Harv L Rev 49 (1923); Charles Mcllwain, The American Revolution: A Constitutional Interpretation (Cornell, 1924); Mcllwain, Constitutionalism, Ancient and Modern (cited in note 15); Wright, American Interpretations of Natural Law (cited in note 11); Wright, The Early History of Written Constitutions (cited in note 4); Julius Goebel, King's Law and Local Custom in Seventeenth Century New England, 31 Colum L Rev 416 (1931); Corwin, 42 Harv L Rev at 386 (cited in note 10); Barker, Natural Law and the American Revolution (cited in note 13); Samuel E. Thorne, Dr. Bonham's Case, in Essays in English Legal History 269 (Hambledon, 1985). McIlwain's studies provoked notable controversies with two other scholars of the period, Plucknett and Schuyler. For a discussion of the McIlwain-Plucknett controversy, see W. Gough, Fundamental Law in English Constitutional 
devote only a few pages to the rhetoric of English rights, preferring to characterize the political theory of the Revolution as "a magnificent invocation of first principles," a declaration of "special trust" in "the school of natural law."

From the late 1950's onward, by contrast, historians laid considerably less emphasis on "first principles."27 Particularly after the appearance of Pocock's The Ancient Constitution and the Feudal Law, the prominence of "first principles" steadily dwindled in accounts of Anglo-American revolutionary ideology, and the prominence of "ancient English rights" steadily grew. Historians began to see the revolutionary lawyers as committed not to the natural law abstractions of Enlightenment France, but rather to the seventeenth-century English constitution and to the seventeenth-century legal order of the English countryside. They saw them as "romantic conservatives," living late in the eighteenth century, with legal values abandoned generations earlier in metropolitan Britain. ${ }^{28}$ This school of historians made little of references to natural law.

Indeed, constitutional historians had come full circle: where historians once read the references to natural law in the American Revolution with avid interest and were merely puzzled or irritated by references to the "Rights of Englishmen," they now read avidly for references to the "Rights of Englishmen" and were puzzled by references to natural law. By 1981, J. P. Reid could maintain that the American Revolutionaries paid no heed to natural law, despite

History 30 (Rothman, 1955). For the Mcllwain-Schuyler controversy, see Barbara A. Black, The Constitution of Empire: The Case for the Colonists, $124 \mathrm{U} \mathrm{Pa} \mathrm{L}$ Rev 1157, 1157-61 (1976).

This emphasis on natural law during these years was, perhaps, a product of its time. These scholars wrote at a moment when democracy and liberal values seemed secure only in America and on the far western fringe of Europe. Thus, they naturally conceived of the American and French Revolutions as belonging to a single, isolated "Atlantic Civilization": the home of an Enlightenment tradition of universal liberty starkly opposed to the dark German world of historical relativism. After victory in World War II diminished our sense of embattled solidarity with France, scholars tended to see the American tradition as unique, but still rooted in natural law.

${ }^{28}$ Clinton Rossiter, Seedtime of the Republic: The Origin of the American Tradition of Political Liberty 326, 362 (Harcourt, Brace, 1953). For a discussion of the historiography of the period, see Black, $124 \mathrm{U} \mathrm{Pa} \mathrm{L} \mathrm{Rev} \mathrm{at} 1157$ (cited in note 25).

27 This was particularly true, perhaps, after Peter Laslett's demonstration that Locke's Two Treatises had not, in fact, been written in defense of the Glorious Revolution. See Peter Laslett, The English Revolution and Locke's Two Treatises of Government, 12 Camb Hist J 40 (1956).

38 Hendrik Hartog, Losing the World of the Massachusetts Whig, in Hendrik Hartog, ed, Law in The American Revolution and the Revolution in Law: A Collection of Review Essays on American Legal History 143, 163 (New York, 1981). 
the routine association of the "British constitution" with "the eternal Laws of Nature." Such statements were less "appeals to natural law" than "boasts about the validity and perfection ... of the constitution." ${ }^{2 \theta}$ Custom had once been read out of the record; now it was the turn of natural law.

Most recently, the literature has swung back toward an emphasis on natural law. ${ }^{30}$ But surely it is clear that we cannot allow the historiographical pendulum to swing indefinitely. It is pointless to argue whether the Revolutionaries really cared about custom, or really cared about reason. Manifestly they cared about both at once, and not infrequently identified the two. What we lack is an interpretation that can account for the oddly casual conflation of the law of reason and the custom of Englishmen that prevailed among American revolutionary lawyers and their English contemporaries. We still have not faced our ultimate task: to explain, not what eighteenth-century lawyers thought, but rather how they fell so far short of what we would consider clear thinking.

\section{The Historical Roots of "Mingling" Custom and Reason: The Problem of Proof of Custom}

To understand that failure of clear thinking, we must bring a perspective to American history that includes continental Europe and that extends back to the Middle Ages. America was only one of many early modern legal cultures addicted to the same practice of mixing custom with reason. This was a pan-Western phenomenon; accordingly, it calls for a pan-Western explanation. Moreover, it was a phenomenon with centuries-old roots. The chaotic jurisprudential affairs in America was the long-term result of a collapse of customary jurisdictions that began with the expansion of European state power in the later Middle Ages and accelerated in the early modern period. This collapse made it impossible to prove

20 John Phillip Reid, The Irrelevance of the Declaration, in Hartog, ed, Law in The American Revolution and the Revolution in Law at 46, 67 (cited in note 28). See also John Phillip Reid, Constitutional History of the American Revolution: The Authority of Rights (Wisconsin, 1986); John Phillip Reid, In Defiance of the Law: The Standing-Army Controversy, the Two Constitutions, and the Coming of the American Revolution (North Carolina, 1981); Willi Paul Adams, The First American Constitutions: Republican Ideology and the Making of the State Constitutions in the Revolutionary Era (North Carolina, 1980). For a survey of the hterature along these lines, see Greene, $85 \mathrm{~S}$ Atlantic Q 56 (cited in note 14).

so See, for example, J.G.A. Pocock, Between Gog and Magog: The Republican Thesis and the Ideologia Americana, $48 \mathrm{~J}$ Hist Ideas 325 (1987), discussing John Diggins, The Lost Soul of American Politics: Virtue, Self-Interest, and the Foundations of Liberalism (Chicago, 1984); Isaac Kramnick, Republican Revisionism Revisited, 87 Am Hist Rev 629 (1982). 
custom through the traditional procedure, by interviewing local witnesses. $^{31}$

For westerners from the Dark Ages onward, custom was the fundamental legitimate source of rights. Custom formed the "basic norm," the fundamental source of legitimacy upon which "legal reality," the subjective understanding of the world as including rights, was founded..$^{32}$ What was not customary, was not right. But what was customary could be determined only in local gatherings, in which the local populace, or perhaps the local elders, could arrive at consensus.

From the twelfth century onward, however, European states began gradually to assert their power, slowly eroding local society. As these states grew, they established learned courts-ecclesiastical courts, princely courts, urban courts-in which it was often difficult or impossible to consult local witnesses who might testify as to the nature of customary rules. Yet the lawyers who worked in those courts continued to treat custom as the basic source of legitimacy. As a result, lawyers working in governmental courts faced a dilemma. Custom, the traditional source of legitimacy, dictated that courts consult local witnesses, but they were unable to do so. The problem became acute in the early modern period, when governmental courts displaced local jurisdictions on a large scale. As governmental adjudication became the norm,

31 In offering what could be called a "proceduralist" explanation, I follow the lead of a number of legal historians who have tried to identify the procedural pressures that underlie developments in the airy heights of legal philosophy. And like most of them, I concentrate on the law of proof. See John Langbein, Torture and the Law of Proof (Chicago, 1976), and the hiterature cited in notes 42 and 53.

32 I take the concept of "basic norm," of course, from Hans Kelsen. I am aware that Kelsen's formulation of this concept changed notably over the course of his career-so much so, indeed, that the concept has been treated as more or less worthless. See, for example, Richard Tur and William Twining, eds, Essays on Kelsen 8-9 (Clarendon, 1986); Iain Stewart, The Critical Legal Science of Hans Kelsen, 17 J L \& Society 273, 295-97 (1990). I am also aware that Kelsen offered accounts of the place of custom in legal systems that differ from the account of custom I will offer here. See, for example, Richard Tur, The Kelsenian Enterprise, in Tur and Twining, eds, Essays on Kelsen 150, 153. Finally, I am aware that Kelsen used his theory to describe objective and not subjective right. Nevertheless, I think the concept of the "basic norm" can be usefully employed here, in a way fundamentally faithful to Kelsen's approach. See Hans Kelsen, Was ist ein Rechtsakt?, in Hans Klecatsky, ed, 2 Die Wiener Rechtstheoretische Schule 1381-93 (Europa, 1968). Within the historical context I describe, in which centralized courts encroached upon the countryside, the commitment to respect local custom did constitute a basic norm. It is true that this basic norm had what Kelsen might regard as an "impure" origin, in political conflict. Nevertheless, custom was invoked to govern the norm-making of the centralized legal system in a Kelsenian "pure" way; and it continued to be so invoked long after its "impure" political origin had been forgotten. 
early modern lawyers found themselves almost wholly cut off from local witnesses. Lacking local witnesses, early modern lawyers were forced to seek an alternative means of determining custom. The alternative they chose was to blend customary and natural law into a peculiar concoction, which they called the "common custom of the realm," and which they embodied in treatises that could be consulted in lieu of consulting local witnesses. The consequence was a thorough confusion of custom and reason, a confusion still present when the American Revolution began.

\section{A. The Middle Ages on the Continent: "Proving" Local Custom}

In the dark centuries after the collapse of Carolingian authority, the populace of western Europe resolved almost all of its disputes in village and manorial gatherings. In such gatherings, the local populace would arrive at consensus with little or no intervention from centralized governmental forces. ${ }^{33}$

But beginning in the twelfth century, new governmental forces appeared on the European landscape, bringing with them new kinds of courts. Princely, urban, and ecclesiastical courts began to encroach upon the western European countryside which had been dominated by these local gatherings. ${ }^{34}$ To be sure, even as new courts appeared, the local gatherings still survived. Indeed, throughout the later Middle Ages, local gatherings presumably continued to manage most dispute resolution. ${ }^{35}$ Nevertheless, after the twelfth century, not all disputes were resolved in such local gatherings. Some litigation, especially litigation involving large sums and momentous issues, made its way into new governmental courts staffed by lawyers trained in one form or another of learned law.

One might suppose that the lawyers who staffed these courts might have been hostile to local customary traditions. After all, learned lawyers represented the sophisticated traditions of the royal and urban centers. But, such was not the case. On the contrary, lawyers generally committed themselves to respecting local

ss For a description of these societies, see Peter Brown, Society and the Supernatural: A Medieval Change, in Society and the Holy in Late Antiquity 302, 310-11 (California, 1982).

34 See the surveys of institutional development by Gunter Gudian, Die Grundlegenden Institutionen der Länder, in Helmut Coing, ed, 1 Handbuch der Quellen und Literatur der neueren Europäischen Privatrechtsgeschichte 401 (C.H. Beck', 1973); and Winfried Trusen, Die gelehrte Gerichtsbarkeit der Kirche, in id at 467.

${ }^{35}$ See, for example, the remarks of John H. Baker, An Introduction to English Legal History 26-32 (Butterworths, 3d ed 1990). 
customary tradition. This was, broadly speaking, true all over Europe. Learned lawyers (with the possible exception of Church lawyers) ${ }^{36}$ declared that local customary rights should be respected by centralized justice. ${ }^{37}$ Judges in the new courts were obliged to swear an oath to respect customary rights. ${ }^{38}$ This commitment to respect customary rights was, moreover, invested with definite political significance: learned lawyers declared that custom expressed the "voluntas populi"- the "will of the people."

But the lawyers' commitment to respect "the will of the people" was subject to substantial practical and theoretical limits. Governmental courts could not apply customary rules unless they knew exactly what the governing customary rules in any litigation might be. And determining custom was no easy proposition. Cus-

${ }^{36}$ For the attitude of the earlier church lawyers, see Andre Gouron, Non dixit: Ego sum consuetudo, 74 Zeitschrift der Savigny Stiftung für Rechtsgeschichte (Kanonistische Abteilung) 133 (1988). For later medieval attitudes, which were quite complex, see Richard H. Helmholz, Roman Canon Law in Reformation England 12-20 (Cambridge, 1990), and the literature cited therein.

${ }^{37}$ For the status of custom as "unlimited" in the absence of legislation (see also note 69 and accompanying text), see Pierre-Clément Timbal, Coutume et Jurisprudence en France au Moyen Age, in 52 La Coutume 227, 227-32 (Recueils de la Société Jean Bodin pour l'Histoire Comparative des Institutions, 1989). The Milanese jurist Obertus de Orto, for example, stated the principle of the supremacy of custom in very definite terms ("The Roman laws are of no mean authority, but their force does not extend so far as to defeat usage or custom."). Obertus de Orto, De Feudis sive eorum Consuetudine Mediolanensi in Jacques Cujas, Novellarum Constitutionum Impp. Iustiniani Expositio 110 (Ioannas Gymnicus, 1569). For a recent discussion of Obertus's statement, see also Gerard Giordanengo, Le Droit Féodal dans les Pays de Droit Écrit: L'Exemple de la Provence et du Dauphiné 126 (École Française de Rome, 1988). Obertus's statement reversed the sense of a famous declaration in the Code, C. 8, 52, 2. For other Italian examples, along, valuably, with English ones, see Andre Gouron, Coutumes contre loi chez les premiers glossateurs, in Andre Gouron and Albert Rigaudiere, eds, Renaissance du Pouvoir legislatif et Genese de l'Etat 117 (Montpellier, 1988); for France, see Jean-Francois Poudret, Rapport de synthèse: Connaissance et Preuve de la Coutume en Europe occidentale au moyen âge et a l'époque moderne, in $52 \mathrm{La}$ Coutume 511, 513 (Recueils de la Société Jean Bodin pour l'Histoire Comparative des Institutions, 1989) and the hterature in the following notes. The earliest revivalists of Roman law had, however, a very different attitude, which is described in James Whitman, The Lawyers Discover the Fall of Rome, 9 L \& Hist Rev 191 (1990).

${ }^{38}$ See Woldemar Engelmann, Die Wiedergeburt der Rechtskultur in Italien durch die wissenschaftliche Lehre 90 (K.F. Kochler, 1938). See also Vincenzo Piano Mortari, Potere Regio e Consuetudine Redatta nella Francia del Cinquecento, in 1 Quaderni Fiorentini 142-43 n 22 (1972) ("the judges in this realm are bound by oath to maintain both ordinances and local customs") (quoting Rebuffi).

s9 See Ennio Cortese, 2 La Norma Giuridica: Spunti Teorici nel Diritto Comune Classico 101-239 (Giuffre, 1964). For France, where this view was represented, among the Orléanais jurists, particularly by Pierre de Belleperche, see Laurent Mayali, La Coutume dans la Doctrine Romaniste au Moyen Age, in 52 La Coutume 11, 20 (Recueils de la Société Jean Bodin pour l'Histoire Comparative des Institutions, 1989); and Laurent Waelkens, $L a$ Thêorie de la Coutume à l'école de Droit d'Orléans (XIIIe siècle), 52 La Coutume 33, 35. 
tomary dispute resolution took place in local gatherings, presided over by elders and leaders who sought to foster local consensus. By contrast, governmental courts were presided over by jurists without local ties, ignorant of local practices. ${ }^{40}$ Such men could not adjudicate in the way local leaders did, by assembling the populace and engineering consensus through suasion and authority. Lacking local ties, these jurists inevitably had to rely more on awe and less on authority than did local elders and leaders. ${ }^{41}$ And without the entire community before them, they could not supervise consensus formation. They could only do what learned lawyers are trained to do: apply some defined rule to the particular parties before them.

Nevertheless, these learned jurists set out to replicate the dispute settlement of local gatherings and to apply the rules that the local gathering would have applied. This meant, of course, determining what those local rules might be-a business referred to as "proving" custom. Learned lawyers in the later Middle Ages spent much intellectual capital searching for some means of "proving" custom. ${ }^{42}$ From the twelfth century on, lawyers in England, France, and northern Italy widely accepted, in one form or another, the proposition that some sort of testimony of local witnesses was in order. ${ }^{43}$

Of particular importance was a procedure pioneered in thirteenth-century northern France. Called the "enquête par turbe,"44 this procedure required the systematic interrogation of local wit-

40 See Jacques Vanderlinden, La Coutume dans le Droit Français des 'Pays des Coutumes' aux XVIe, XVIIe et XVIIIe siècles, in 52 La Coutume 271, 289 (Recueils de la Société Jean Bodin pour l'Histoire Comparative des Institutions, 1989).

4 For a thouglitful discussion of the contrast between law in tbe presence and in the absence of officials with central authority, see Simon Roberts, The Study of Dispute: Anthropological Perspectives, in John Bossy, ed, Disputes and Settlements: Law and Human Relations in the West 1, 10-24 (Cambridge, 1983).

${ }^{2}$ See S.F.C. Milsom, The Legal Framework of English Feudalism 2 (Cambridge, 1976) ("We may do better with our own questions if we try to understand theirs; and their questions were mostly about proof."). See also Wolfgang Wiegand, Zur Herkunft und Ausbreitung der Formel 'Habere Fundatam Intentionem', in Sten Gagner, et al, eds, Festschrift für Hermann Krause 126 (Bohlau, 1975); Wolfgang Wiegand, Studien zur Rechtsanwendungslehre der Rezeptionszeit (Gremer, 1977).

4s A variety of forms are surveyed in Poudret, $52 \mathrm{La}$ Coutume at 511 (cited in note 37). For the important Italian tradition, see id at 537-39 and note 45 below. For England, see Section IID. The German-speaking world, as Poudret points out, should probably be viewed separately, even though German solutions were in many ways closely related to western ones. Id at $518,539$.

14 This procedure almost certainly had roots much further back in the Middle Ages. See the discussion of Poudret, $52 \mathrm{La}$ Coutume at 523 (cited in note 37) (disagreeing with Laurent Waelkens, L'Origine de l'Enquête par Turbe, 53 Tijdschrift voor Rechtsgeschiedenis 337 (1985)). 
nesses. As one leading fourteenth-century French lawyer described the procedure, custom was to be "proved by a meeting of ten men worthy of faith."45 A 1270 ordinance of Saint Louis laid out the following details:

Several wise men, in good repute, are to be called. Once they are called, the custom is to be proposed to them by the mouth of one of their number. The custom having been proposed, they are to declare and honestly transmit what they know and believe and have seen to be the practice with regard to the custom in question. Upon the swearing of an oath, they are to stand off to the side, deliberate, and communicate their deliberations, saying among which persons they have seen the custom practiced, who performed it in what case and in what place, if it has been the subject of a judgment and what the circumstances were, and all of this is to be reduced to writing and sent to the court under the seals of the inquisitors, and they are also to be separately interrogated on what they have said. ${ }^{46}$

This procedure was laden with political meaning. The practice of interviewing local "wise men," as described here, was designed to manifest scrupulous deference to the "will" of the local "people." Note how this procedure dramatized the autonomy of the ten wise persons testifying, leaving them free to define the custom them-

45 See Kelley, The Human Measure at 100-01 (cited in note 5). See generally P. Guilhiermoz, La Persistance du Caractère Oral dans la Procédure Civile Française, 13 Nouvelle Revue Historique de Droit Français et Étranger 21 (1889). This principle was accepted in Italy, homeland of learned law, as well. The international learning was summarized by one great Italian scholar as follows: "The Doctors [i.e. the learned jurists] declare that witnesses are to be produced just as in other cases, and that they are to swear an oath and be examined individually. Pierre [de Belleperche] says that laymen do not believe us on this point, since they do not say that this sort of full proof is required; but rather only half proof-i.e., that the judge shall examine witnesses and, drawing conclusions from what they say, shall judge accordingly . . . "Wiegand, Studien zur Rechtsanwendungslehre at 114 (cited in note 42) (quoting Cino da Pistoia). For the importance of Orleanais learning in the development of this tradition, see Mayali, 52 La Coutume at 15 (cited in note 39).

${ }^{10}$ Rene Filhol, La preuve de la coutume dans l'ancien droit français, 17 La Preuve 357, 361 (Recueils de la Sociétê Jean Bodin pour l'Histoire Comparative des Institutions, 1965) (quoting and interpreting the 1270 ordinance). Compare the manner in which Jean des Mares described the law in his fourteenth century Décisions: If there was no written source for a custom, "in order properly to prove custom, usage or style when alleged, the proof in question must be made and reported in turbe [the formal gathering of witnesses] by ten knowledgeable customary witnesses, giving certain and positive declaration ["cause"] of their depositions . . . ." Henri Beaune, Introduction a l'étude historique du Droit Coutumier Français, jusqu'a la Rédaction officielle des Coutumes 446 n 1 (Librarie Briday \& Larose Editeur, 1880). 
selves, and allowing them to stand aside, without interference. ${ }^{47}$ There was great political significance here: By requiring no fewer than ten witnesses, French lawyers obeyed the maxim "decem faciunt populum"-_"ten makes 'the people'."48 Deference to "the people" is, indeed, precisely what this procedure acts out-deference on the part of a weak, but expanding, royal government. ${ }^{49}$

This procedure of interviewing "the people" may, on first glance, seem a simple and workable solution to the problem lawyers faced. But simple solutions are rarely also workable, and in actual practice, this procedure seems to have begun breaking down by the end of the thirteenth century. ${ }^{50}$ Part of the problem was human nature: at least some jurisdictions required unanimity, which is never easy to achieve. ${ }^{51}$ But the deeper problems had to do with the very design of the procedure lawyers had adopted. In the case of simple, widely acknowledged local practice, the ten "wise men" could easily produce a rule. But in all probability, there was frequently no simple, widely acknowledged local practice.

For, recent literature suggests, the very idea of a definite "rule" had somewhat doubtful meaning in the local societies to which governmental courts turned for witnesses. Professor Peter Brown has described the law-making of pre-twelfth-century societies as follows:

[T] hese are small face-to-face groups. We are in a Europe of low overall population where human beings were still cramped into long-inhabited settlements. These settlements could be populous enough in themselves, but they were isolated from

47 I should note, however, that "by the mouth of one of their number," refers, according to one recent authority, to the rapporteurs of the custom, not to the customary witnesses. Waelkens, 53.Tijdschrift voor Rechtsgeschiedenis at $339 \mathrm{n} 20$ (cited in note 44).

48 Adhemar Esmein, Decem faciunt populum, in 1 Mélanges P. F. Girard 457-73 (Librairie Arthur Rousseau, 1912).

40 This practice of consulting witnesses was a legitimating procedure, in the fullest sense of the phrase: it was intended to legitimate the activity of a state that might otherwise be regarded as dangerously intrusive. In so stating, I deviate from the concept of "legitimating procedure" in Niklas Luhmann, Legitimation durch Verfahren 122 (Luchterhand, 1969) ("Legitimation is the institutionalisation of the recognition tbat decisions are binding.") My treatment differs from Luhmann's in two critical respects. First, Luhmann treats "legitimation through procedure" as a feature of modern liberal societies. See id at vii, 11. I am of course invoking the concept to deal witl a very mucl pre-modern and un-liberal order, and to that extent am un-Luhmannian. Second, and most important, the activity of the state is curiously absent from Luhmann's account.

so See Poudret, 52 La Coutume at 514 (cited in note 37).

s1 For the unanimity requirement, see id at 513. But see also the cliallenge by Waelkens, 53 Tijdschrift voor Rechtsgeschiedenis at 339 n 20 (cited in note 44). 
others by stretches of woods and poor communications. The extended kin group is the primary unit of society, a fact studiously maintained and defined by the blood feud. Safety and protection still rested on coagulations of kinsmen and dependents in small, intense groups. . . . The greatest explicit ideal of the early Middle Ages is a minimal one of peace and, above all, concord: this amounted to the maintenance of a minimal consensus in a face-to-face society made up of evenly balanced family groupings. ${ }^{52}$

After the twelfth century, to be sure, local society grew in sophistication. Nevertheless, much of what Professor Brown has described would still have been the case. "Law," in these societies of warriors and farmers, maintained peace and cooperation in matters critical to communal survival: the avoidance of blood feud; the working of common fields and the mounting of common defense; ${ }^{53}$ manorial tenures. ${ }^{54}$ The emphasis was on reconciling quarreling parties, on "lower[ing] the emotional temperature [by] thrashing out the problem aloud." It would hardly always be the case that these societies acknowledged some clear customary rule. Local gatherings would always give weight to traditional solutions, to the question of "what do we usually do?"5s But for these illiterate people, remembering traditional solutions was not easy. ${ }^{57}$ Moreover, they could not maintain consensus without flexibility:

What matters is the present decision, the choice made now. That is guided or not by the past, but cannot be "wrong" be-

${ }^{2}$ Brown, Society and the Supernatural at 310-11 (cited in note 33).

ss Paul Hyams, Trial by Ordeal: The Key to Proof in the Early Common Law, in Morris Arnold, et al, eds, On the Laws and Customs of England: Essays in Honor of Samuel E. Thorne 90, 95 (North Carolina, 1981).

ss See S.F.C. Milsom, Historical Foundations of the Common Law 99-116 (Butterwortlis, 2d ed 1981); George C. Homans, English Villagers of the Thirteenth Century (Russell \& Russell, 1960).

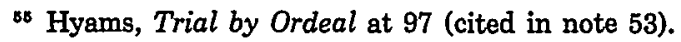

${ }^{66}$ Milsom, Historical Foundations at 1 (cited in note 54).

87 See Hyams, Trial by Ordeal at 96 (cited in note 53) ("Because tliere is no accurate memory of past decisions, each new case reviews the good old custom in the context of the current situation."). A related point is made in the French literature: custom was "unformulated" ("droit non formulé"). See John Gilissen, La Coutume dans les 'Pays de ParDeça" (Belgique, Pays-Bas, Nord de la France) (XIIe-XVIIIe siècles), in 52 La Coutume 295, 298 (Recueils de la Société Jean Bodin pour l'Histoire Comparative des Institutions, 1989). 
cause of it. It is the past that must give way, and then the present will have refined or modified the custom. ${ }^{88}$

When learned lawyers set out to "prove" custom by consulting local witnesses, they were thus often asking the wrong question. In matters of any difficulty, local law-making involved not agreeing upon "the rule" but agreeing upon a peaceful solution. In such circumstances, it is not surprising that learned lawyers often failed to get witnesses to produce any rule at all. ${ }^{80}$ Nor is it surprising that, even when they got a rule, they did not always get perfect agreement on that rule. In the 1319 case of Salvin Lombard against Jean de Senlis, for example, both parties produced substantial numbers of witnesses. But while Salvin Lombard produced seventeen witnesses to swear to his version of the "rule"; Jean de Senlis produced only fourteen witnesses, of whom only six would swear to his version. ${ }^{60}$ In describing this case, it may be quite misleading to use the phrase, "there was no agreement over the rule." Perhaps we should rather say, "there was local conflict, in which Salvin Lombard had substantially more supporters than did Jean de Senlis."B1 To the extent the latter phrase is correct, the French court that decided in Salvin Lombard's favor was not "applying" a "rule." Rather, it was throwing the coercive weight of the central government behind the stronger local party (or perhaps behind the stronger local kin group) ${ }^{62}$

But the learned lawyers working in the 1319 court that heard the case of Salvin versus Jean could hardly have accepted such a characterization. The logic of political deference embodied in the 1270 ordinance of Saint Louis required them to defer to local custom. They were to enforce a local consensus, not take sides in a local dispute. But the locals had not formed a consensus. Indeed,

68 Milsom, Historical Foundations at 1 (cited in note 54). Unlike process in court, the legal process in these local gatherings, involved communal discussion that would seem, to a learned lawyer, to ramble quite aimlessly. Hyams, Trial by Ordeal at 97 (cited in note 53).

69 See the examples in Piero Craveri, Ricerche sulla Formazione del Diritto Consuetudinario in Francia 27 (Giuffì̀, 1969).

10 Discussed in Filhol, $17 \mathrm{La}$ Preuve at 362 (cited in note 46).

81 This is particularly true to the extent that the witnesses summoned hy the parties were, hike witnesses in the compurgation of the earlier Middle Ages, swearing not to fact hut to their willingness to support their kinsman. See Marc Bloch, 1 Feudal Society 124-25 (Routledge \& Kegan Paul, 1961). That there is, however, something more complex going on in this dispute is surely suggested hy the fact that only six of Jean's witnesses would swear to his version of the rule. Clearly serving as Jean's witness (qua kinsmen?) and swearing to Jean's right were conceived of as separate propositions by these witnesses. At any rate, it is clear enough that there was no universal agreement on a rule here.

ox Indeed, the very fact that both parties produced witnesses, rather than the judge engaging in inquisitorial investigation, was itself symptomatic of the decline of the institution. See the discussion of Poudret, $52 \mathrm{La}$ Coutume at 528 (cited in note 37). 
the more governmental courts displaced local gatherings, the less likely it was that consensus could ever form.

There was thus a worm in the rose of customary jurisprudence from its very beginning. It was, in the last analysis, impossible to abstract the substance of custom from the process of local discussion; ${ }^{63}$ learned lawyers needed a "rule" that they could never count on getting. The problem, moreover, could only grow worse as mobility increased and local society began to break down in the later Middle Ages.

Lawyers did have some escape routes. It was not absolutely necessary for learned lawyers to consult live witnesses in every instance. The process of interrogating witnesses produced a written notation of a customary rule, which in theory courts could use in later cases. Particularly in southern Europe, written compilations of custom, in the form of charters or custumals ${ }^{64}$ were used in lieu of witnesses. ${ }^{65}$ Beginning in the thirteenth century, this practice of using written sources appeared in northern Europe as well. ${ }^{86}$ But custumals were a distinctly limited source, for they were strictly construed. They could only attest to the specific customs they recorded; a court could not apply the custumal to an unprovided-for case. ${ }^{67}$ This created a most important difficulty for customary jurisprudence: the problem of gaps. The principle of strict construction meant that customary law reasoning could not resolve an issue

6s See Fredric Cheyette, Custom, Case Law, and Medieval 'Constitutionalism': A Reexamination, 78 Pol Sci Q 362 (1963).

84 For convenience, I use the term "custumal" to refer not only to the northern custumals for which the term is typically used, but also statutes declaratory of custom. Not all statutes were, however, declaratory of custom. See notes 65 and 66 .

BS The practice of developing written custumals was particularly common in the citystates of Italy and Provence; indeed, city-states typically forhade judges to decide cases by reference to any source other than written compilations of communal custom. See, for example, Engelmann, Die Wiedergeburt der Rechtskultur in Italien at 90 (cited in note 38); Poudret, $52 \mathrm{La}$ Coutume at 532 (cited in note 37). Mayali, $52 \mathrm{La}$ Coutume at 16-17 (cited in note 39 ), discusses in learned detail the substantial difficulties lawyers experienced in accepting the notion of written custom-a notion at odds with the Roman tradition that custom was, by definition, not written.

${ }^{38}$ See, for example, the discussion in Kelley, Human Measure at 102 (cited in note 5), with citations to further literature. For the history of such written declarations of custom in Italy, see Whitman, $9 \mathrm{~L}$ \& Hist Rev at 200 (cited in note 37). Also valuable as a survey of statutes declaring custom is Armin Wolf, Die Gesetzgebung der entstehenden Territorialstaaten, in Helmut Coing, ed, 1 Handbuch der Quellen und Literatur der neueren Europäischen Privatrechtsgeschichte 517 (C.H. Beck', 1973), although Wolf treats not only such declaratory statutes, but also innovative legislation.

${ }^{87}$ See, for example, Filhol, $17 \mathrm{La}$ Preuve at 361 (cited in note 46); Guilhiermoz, 13 Nouvelle Revue Historique de Droit Français et Étranger at 21 (cited in note 45). See also the evidence of Rebuffi, discussed in note 82 and accompanying text. 
that a custumal had not directly addressed. Thus, introducing written sources offered only the narrowest of theoretical exceptions to the general rule that respecting custom meant interrogating the locals. ${ }^{68}$ Moreover, there were practical difficulties with written sources. Charters-rare and valuable things that they were-were not easy for litigants to come by. Many localities had no custumals, and even the custumals that existed resolved only a limited range of disputes.

Added to these practical difficulties were a pair of critical theoretical provisos that limited the governmental courts' willingness to defer to custom. First, courts treated royal or urban legislation as trumping custom. ${ }^{69}$ Finally, and fatefully for my tale, courts typically insisted that customs would only be respected if they were "reasonable."

These practical and theoretical considerations meant that centralized courts, despite their avowed deference to custom, must have failed to apply it often. What, then, did they do? According to juristic doctrine, in the absence of legislation, they applied general law. This general law might be Roman or Canon law, which had, in theory, universal application to all litigants, whatever their

as Another important exception to the general requirement of live testimony should also be noted. Some customs, lawyers held, were sufficiently "notorious" not to need proof. Again, Cino de Pistoia may be quoted: "Jacques de Revigny concedes that if [a custom] is notorious one does not allege it-such as the English custom that the eldest child inherits all ...."Wiegand, Studien zur Rechtsanwendungslehre at 104 (cited in note 42). For the authority of the rule "notoria non egent probatione" ("notorious customs need not be proven") in later medieval France, see Filhol, 17 La Preuve at 360 (cited in note 46); and in Italy, Poudret, 52 La Coutume at 538-39 (cited in note 37). This was not, however, true, in the thirteenth century. See Poudret, $52 \mathrm{La}$ Coutume at 526-27.

But this exception, it is important to note, was probably distinctly limited. The notoriety of a "notorious" custom, at least in France, could probably be assumed only where the custom in question was not challenged by either litigant. Filhol, $17 \mathrm{La}$ Preuve at 360 (cited in note 46); Poudret, $52 \mathrm{La}$ Coutume at 526 (cited in note 37). But see Gilissen, $52 \mathrm{La}$ Coutume at 304 (cited in note 57) (custom notorious only if already known to judge).

es It should be noted that legislation at this time was unusual. For the battles over the status of legislation, see Mayali, $52 \mathrm{La}$ Coutume at 14 (cited in note 39); and the discussion and citations in Whitman, $9 \mathrm{~L} \&$ Hist Rev at 200-01 (cited in note 37).

${ }^{70}$ On this tradition, see, for example, Frederick Pollock, The History of the Law of Nature: A Preliminary Study, 1 Colum L Rev 11, 17-18 (1901); Thomas Grey, The Origins of the Unwritten Constitution: Fundamental Law in American Revolutionary Thought, 30 Stan L Rev 843, 852-54 (1978); and the comments of Albert Kiralfy, Custom in Mediaeval English Law, in 52 La Coutume 379, 383 (Recueils de la Société Jean Bodin pour l'Histoire Comparative des Institutions, 1989).

This tradition, I should note, of course helped pave the way for the confusion I trace. But in itself, it could only have led to the belief that isolated customs must somehow be consistent with a system of reason. This tradition justified deviation away from custom, not supplementation of custom. And only supplementation could claim the ideological force of custom as its own. See note 109. 
local origins (especially in Italy): ${ }^{71}$ The general law might also be some compilation of customary rules from a prominent jurisdiction, such as the custom of Paris in France. ${ }^{72}$ This general law was to be applied, it should be emphasized, only when the existence of local customary right could not be proven; if proven, local custom "broke," or trumped, learned law. But proof was difficult, and general law must have been applied frequently.

The resulting order was, from a political point of view, odd indeed. In theory, litigants in a governmental court had a right to expect that their local rule would be applied to their case. But actual practice in those courts was at sharp variance with that theory. The purportedly custom-bound courts must often have applied learned law quite alien to the litigants before them.

This lack of fit between norm and practice was so striking that one might expect to have seen a crisis of faith in the legal system. How could courts declare their deference to local custom while in fact applying rules drawn from expensive manuscripts produced in Orléans and Padua? ${ }^{73}$ Nevertheless, it would not be surprising if there was no easily discernible general crisis of faith in the Middle Ages. In practice, so many disputes were still resolved locally that there need not have been great tension between the norms of custom and the actual practices of litigation. The legal order was therefore, perhaps, fundamentally stable in the early fifteenth century.

B. The Early Modern Period on the Continent: The Evidentiary Crisis of Custom

But in the later fifteenth and sixteenth centuries came a surge in the growth of state power, and the collapse of local society accelerated. As the great early modern states grew in weight and au-

71 For a survey of medieval legal systems and traditions, see generally the contributions to Coing, ed, 1 Handbuch der Quellen (cited in note 34). Even when such learned law was apphed, however, acknowledgment of the normative supremacy of custom was made: the opinions of the learned lawyers were viewed as having force of law only because they were "custom" of the courts. See Engelmann, Wiedergeburt der Rechtskultur in Italien at 212 (cited in note 38).

${ }^{72}$ See Poudret, $52 \mathrm{La}$ Coutume at 516 (cited in note 37). See also the description of this system in James Whitman, The Legacy of Roman Law in the German Romantic Era: Historical Vision and Legal Change 7-16 (Princeton, 1990).

7s For the concept of "legitimation crisis," see, of course, Jürgen Habermas, Legitimation Crisis (Beacon, 1975) (translated by Thomas McCarthy). However, Habermas most often has in mind more complex social orders than the ones I deal with. Where Habermas does discuss pre-modern societies (see id at 19-20), I find his interpretation unpersuasive. 
thority, so too did governmental courts. ${ }^{74}$ Courts multiplied, gained in social prominence, and expanded their jurisdiction throughout northern Europe. ${ }^{78}$ Especially in the sixteenth century, governmental courts decided more matters, and ones of greater variety. By a kind of hydraulic process, dispute settlement was drawn out of the dwindling local gatherings and into the central courts.

As a result, the tensions already inherent in the medieval legal order began to magnify. What had been a stable lack of fit between norms and legitimating procedures became unstable. Theoretically, it should be emphasized, nothing changed. The medieval system survived, in its essentials; the primacy of customary law was still, for the most part, accepted. ${ }^{76}$ But the local society that had been the home of custom was vanishing. And where local gatherings once resolved the bulk of disputes, centralized courts now resolved them.

The result was an evidentiary crisis of custom. As local gatherings gave way to governmental courts, larger and larger numbers of litigants found themselves in governmental courts in which their customary rights were safe in theory, but were in practice impossible to prove. By the same token, larger and larger numbers of jurists faced cases-often on novel issues-which needed disposition. This was, it must be emphasized, an evidentiary crisis, not a theoretical one. Theoretically, customary law retained its primacy, ${ }^{77}$ but litigants, to their distress and outrage, had to produce testimony from local witnesses whom the learned lawyers would accept. ${ }^{78}$ And those lawyers were, to their chagrin, bereft of rules.

${ }^{74}$ See Filippo Ranieri, 1 Recht und Gesellschaft im Zeitalter der Rezeption; Eine rechts- und sozialgeschichtliche Analyse der Tätigkeit des Reichskammergerichts im 16. Jahrhundert 147-55 (Böhlau, 1985).

${ }^{75}$ The reasons for this shift from countryside to governmental courts are uncertain. The tendency among scholars, and my own tendency here, is to describe it as an aspect of the extension of state power. It has been suggested that the accelerating commercialization of society, which gave rise to disputes unresolvable by traditional methods, was also a factor: "the changes set into motion by economic expansion and population growth were the fundamental cause of much of the increase in litigation recorded in Castile's courts. . . . Custom ... a appears to have been unable to resolve the conflicts of peasants who were rapidly being drawn into the orbit of urban life." Richard Kagan, Lawsuits and Litigants in Castile, 15001700136 (North Carolina, 1981), though see also Kagan's qualifications, id at 137.

${ }^{76}$ See, for example, Vanderlinden, 52 La Coutume at 279-80 (cited in note 40). Of course, there were exceptions. See for example, Pierre Lizet's championship of Roman law, discussed in Rene Filhol, Le Premier Président Christofle de Thou et la Réformation des Coutumes 126-66 (Librairie du Recueil Sirey, 1937).

${ }^{77}$ For Spaim, see Kagan, Lawsuits and Litigants at 28 (cited in note 75) ("customs defeat the statute and have more force than law") (quoting Jerónimo Castillo de Bobadilla).

${ }^{78}$ Particularly poignant examples of the resulting distress and outrage have been preserved from the literature of the era of the German peasant wars. The peasants of Württem- 
Remarkably, lawyers faced with this evidentiary crisis did not abandon the procedural precepts of the Middle Ages. On the contrary, they generally remained faithful to medieval doctrine, even in a sixteenth-century world in which that doctrine had ceased to make procedural sense. But, in order to remain faithful to medieval doctrine, lawyers needed some new means of "proving" custom, or at least some suitable means of supplementing such customs as they had evidence of.

The search for new methods of "proving" or supplementing custom became the governing task of the sixteenth and early seventeenth centuries-particularly in France, the home of the greatest of the new princely states. Throughout the later Middle Ages, French lawyers had compiled custumals. In the middle of the fifteenth century, the French state had commanded the written redaction of all local customs in an ordinance that declared its willingness to abandon the practice of interviewing witnesses as completely impractical. ${ }^{79}$

However, French lawyers did not begin to redact local customs until the end of the fifteenth century. ${ }^{80}$ When they did so, they remained obedient to medieval legitimating procedure in a variety of ways. They continued to hold that custumals had force of law only if accompanied by a record of oral testimony on the customs in question. ${ }^{81}$ And they continued to require that issues for which

berg, for example, demanded in 1514 that "the doctors [i.e., learned jurists] stop interfering with the courts and practices and old customs of the towns and villages, as it was in the old days." Günther Franz, ed, Quellen zur Geschichte des Bauernkrieges 51 (R. Oldenbourg, 1963). But the pattern was hardly confined to Germany. All over Europe, hitigants were horrified to find their fates in the hands of learned lawyers. See the excellent general discussion in A.M. Hespanha, Savants et rustiques: La violence douce de la raison juridique, 10 Ius Commune 1 (1983).

79 This was the ordonnance of Montilz-Les-Tours, in Isambert, Jourdan, and Decrusy, eds, 9 Recueil Général des Anciennes Lois Françaises, Depuis l'an 420 jusqu'à la révolution de 1789 202, 252-54 (Belin-Leprieur, 1825).

so For the initial decades of inaction, see, for example, John P. Dawson, The Codification of the French Customs, 38 Mich L Rev 765, 770-71 (1940). See also the descriptions of the French order at the beginning of the sixteenth century, id at 766-67, and Filhol, $17 \mathrm{La}$ Preuve at 366 (cited in note 46). For the French inovement, see Vincenzo Piano Mortari, Diritto Romano e Diritto Nazionale in Francia nel Secolo XVI (Giuffrè, 1962); Vincenzo Guizzi, Il Diritto Comune in Francia nel XVII secolo, 37 Tijdschrift voor Rechtsgeschiedenis 1, 1-7 (1969); Jean Gaudemet, Les Tendances a l'Unification du droit en France, in 1 La Formazione Storica del Diritto Moderno in Europa, 157 (Leo S. Olschki, 1977); Craveri, Ricerche sulla Formazione del Diritto Consuetudinario (cited in note 59); and Klaus Luig, The Institutes of National Law in the Seventeenth and Eighteenth Centuries, 1972 Jurid Rev 193, 203-207.

${ }^{81}$ See, for example, Filhol, 17 La Preuve at 368 (cited in note 46). For the medieval tradition, see Section II. A. 
the new compilations had not provided be resolved through the traditional mechanism of acquiring local testimony. As one French lawyer emphatically put it, "when there is doubt with respect to a custom, we must recur to a proper witness." ${ }^{2}$

Nevertheless, in practice, the old medieval pattern could not survive in its full form. The French lawyers did not redact through the traditional interrogation of ten local persons. Rather, the French monarchy entrusted the task to more dignified gatherings: local assemblies, organized into three estates, which were to approve all customs in the presence of royal commissioners empowered to "correct, add, subtract and interpret." assemblies in this way had the merit of honoring the political sensibilities associated with the idea of custom, but it differed strikingly from the old practices. Local dignitaries gathered under close royal supervision were hardly the sort of local society that villages and manors had been centuries earlier. ${ }^{84}$ To be sure, not all consultation involved the formal convocation of a local assembly: it was still necessary for French lawyers to consult local witnesses for unprovided-for cases. But even when they did consult local witnesses in the sixteenth century it was increasingly their practice to con-

82 Pierre Rebuff, Tractatus de Consuetudine, Usu, et Stylo, in 1 Commentariorum in Constitutiones Regias Gallicas 2, 20 (Carolum Pesnot, 1576) ("We must keep in mind that, whenever the interpretation of a law or custom is in doubt, we must recur to an honest person ['bonum virum'], as Baldus teaches in consil. cccxlviij. ad evidentiam col. ult. in secundo vol ...."). For "bonum virum" as referring to customary witnesses, see the discussion in Filhol, $17 \mathrm{La}$ Preuve at 357 (cited in note 46); and Mayali, $52 \mathrm{La}$ Coutume at 22 (cited in note 39), and the literature there cited. See also the interesting remarks in Luhmann, Legitimation durch Verfahren at 61-62 (cited in note 49). Rebuffi strikingly altered Baldus's original, which spoke of "contractus," not "consuetudo." See Baldi Ubaldi Perusini, 2 Consiliorum Sive Responsorum 194 (Venetiis, 1575). (That Rebuff did so reflects an important fact that I cannot discuss at any length: The contrast between "common law" and "particular law" on the Continent was not just a contrast between "common law" and custom, but also one between common law and any "particular" legal ordering-which, in the eyes of medieval jurists, included the creation of "particular" ordering through the formation of contract. That contract was conceived in this way only evidences, I take it, the tendency to conceive all valid law as "custom" in a world in which custom provided the basic norm. See, for example, Mayali, 52 La Coutume at 26 (cited in note 39)).

The "enquête par turbe," the special interrogation of local customary witnesses, survived until 1667. See, for example, Filhol, 17 La Preuve at 370-71 (cited in note 46). 80).

ss The process is described at length in Dawson, 38 Mich L Rev at 774 (cited in note

34 Moreover, the resolutions of estates may have all too clearly embodied the triumph of the interests of one local class over another. In such circumstances it was difficult (as it may already have been difficult in the Middle Ages) to view the redaction of custom as the recording of shared beliefs, rather than as the intervention of central government on the side of the stronger local party. See Timbal, 52 La Coutume at 232 (cited in note 37). 
sult local lawyers. ${ }^{85}$ Consulting lawyers was at best a dim echo of thirteenth century practices, for, by tradition, lawyers belonged to the world of state power itself, not to the world of local autonomy. ${ }^{86}$

This state of affairs presented French jurists with a dilemma. In theory, custom still reigned supreme. But courts were not "proving" custom in the way that their inherited texts instructed them to do. By the turn of the sixteenth and seventeenth centuries, French jurists were responding with a mix of lamentation and dogged doctrinal conservatism. In the early seventeenth century, Gilles Fortin bemoaned the passing of the medieval rules: "[T]he proof [of custom] was not in books but in assemblies of those who know the practice and ordinary usage." ${ }^{287}$ And Fortin's contemporary Antoine Loysel, author of the leading work on customary jurisprudence, continued to cite the letter of medieval proof practices centuries after they had proven unworkable. ${ }^{88}$

Earlier sixteenth-century French jurists offered more creative responses. To begin with, they defended the practice of using lawyers as customary witnesses. One particularly influential figure, Charles DuMoulin, insisted in 1546 that traditional customary witnesses were corrupt. ${ }^{89}$ The use of such witnesses had oppressed "many good citizens ... in particular orphans and widows." (This was not just shyster's rhetoric: orphans and widows are precisely the persons least certain of a kin group to support them.) Given such corruption and inequity, there was no harm in dropping the

${ }^{86}$ For this development, see Vanderlinden, 52 La Coutume at 280-82 (cited in note 40).

Compare also the accounts in Paul Ourliac and Jean-Louis Gazzaniga, Histoire $d u$ Droit Privé Français de l'An mil au Code civil 147 (Albin Michel, 1985); and Dawson, 38 Mich L Rev at 778 (cited in note 80). For the general rule, see Rebuffi, De Consuetudine at 38 (cited in note 82) ("[T]hirdly, that the practitioners ['practicantes'] of the region for which the customs are being redacted, be in agreement . ..."). For "practicantes" as meaning legal practitioners, see Charles DuCange, Glossarium Mediae et Infimae Latinitatis (Instituti Regii Franciae Typographi, 1845) (s.v. "practicare") J.F. Niermeyer, Mediae Latinitatis Lexicon Minus (E.J. Brill, 1984) (s.v. "practicare"). The French ordinance upon which Rebuffi commented here used the term "Practiciens"-again typically "lawyer" in sixteenth-century parlance. See Huguet, 6 Dictionnaire de la Langue Française du Seizième Siècle 130 (Didier, 1965) (s.v. "praticien"). 85).

se See Ourliac and Gazzaniga, Histoire du Droit Privé Français at 150 (cited in note

87 Kelley, Human Measure at 101 (cited in note 5).

88 Poudret, 52 La Coutume at 529 (cited in note 37).

80 Charles DuMoulin, Oratio de concordia et unione consuetudinum Franciae, in 2 Caroli Molinaei Omnia quae Extant Opera 690 (Paris, 1681) ("Many perfidious witnesses sprang up, people became accustomed to false oaths, subornation, and slander, and evil swelled every day.").

${ }^{80}$ Id. 
traditional practice of interrogating customary witnesses. But that did not, in DuMoulin's view, mean that custom need cease to be the basis of proper law in France. For there was an alternative: humane and patriotic lawyers (and such lawyers, if rare, did exist) ${ }^{91}$ were capable of producing excellent sources of custom. Similarly, Pierre Rebuffi of Montpellier defended the use of lawyers as witnesses by noting that lawyers had direct knowledge of customary rules from everyday experience. ${ }^{92}$

Nor did DuMoulin and Rebuffi stop there. In particular, they took the critical step of abandoning the old rule that written sources be strictly construed. Thus, Rebuffi conceded that recorded customs were not in general to be applied to unprovided-for cases without testimony from witnesses. But he nevertheless contended that it was reasonable to extend recorded customs to "similia"-_similar cases."

DuMoulin went yet a step further. He proposed one of the most influential legal ideas in Europeam history: the idea of "common customary law." $\mathrm{His}$ humane and patriotic lawyers could, he argued, recover the common custom of the entire realm through the compilation and comparison of all French customs. The result would be a written source of custom, easily applicable in courts all over France, which would not require the testimony of corrupt local witnesses..$^{95}$

These jurisprudential ideas were in some measure strained, but all were influential. In particular, DuMoulin's proposed "common customary law" made a great sensation (although not before it stimulated heated debate).${ }^{96}$ A large number of talented lawyers

91 Id at 692. The background to this is the widespread invective against lawyers in the sixteenth century. See Gerald Strauss, Law, Resistance and the State (Princeton, 1986); Donald Kelley, Jurisconsultus Perfectus: The Lawyer as Renaissance Man, 50 Warburg and Courtauld Institutes 84 (1988). Compare also the observations of Luhmann, Legitimation durch Verfahren at 112 (cited in note 49).

92 Rebuffi, De Consuetudine at 38 (cited in note 82) ("since the nearer you are ['viciniores'] the better positioned you are to understand").

os Id at 20 ("customs are not to be extended, except to similia, and when they are favorably [suited to the purpose], as I wrote above q. iij. in x. differentia").

* For a more general statement of DuMoulin's views, see DuMoulin, Oratio at 691 (cited in note 89) ("[I]t can easily be conjectured that all of these customs were originally one, and that with the passage of time they have assumed local variations in different regions; which variety is most lacking in reason and utility ...."). On DuMoulin, see generally Jean-Louis Thireau, Charles Du Moulin (1500-1566): études sur les sources, la méthode, les idées politiques et économiques d'un juriste de la Renaissance (Librairie Droz, 1980). This idea had only the vaguest of medieval precedents. See, for example, id at 120 .

95 See generally, Mortari, Diritto Romano e Diritto Nazionale (cited in note 80).

96 See Gaudemet, Tendances at 167 (cited in note 80) (citing Pierre Hénin); see also id at 181-82. 
in subsequent generations picked up DuMoulin's powerful idea and developed treatises of customary law which they believed were faithful to the spirit of France but did not require the consultation of witnesses. ${ }^{97}$ DuMoulin's notion became, moreover, a favorite both of the partisans of state-building princes ${ }^{98}$ and of their opponents. In particular, the customary law thought pioneered by DuMoulin became deeply entangled with French constitutionalism, embraced by the Huguenot constitutionalist combatants in the French Civil War of the 1560's and 1570's. ${ }^{99}$ Customary law thinking of the DuMoulinian type survived into the French seventeenth century, embraced by a wide variety of successors within the religious-political mainstream. ${ }^{100}$

These new treatments of customary law did not, it is important to note, wholly free themselves from older suppositions. In particular, just as local customs had trumped learned law in the Middle Ages, the newly invented "common customary law" was said to trump the learned law of sixteenth- and seventeenth-cen-

As one lawyer put it, the whole idea of a "common" customary law made little sense, since witnesses often disagreed among themselves: "Who is going to explain to me this 'common reason'? After all, among two or three persons there are often thoroughly diverse and contradictory opinions." Guizzi, 37 Tijdschrift voor Rechtsgeschiedenis at 7 (cited in note 80). Customary law, the objection said, in effect often failed to reflect even the shared understanding of a small village; how could there be any "common customary law" of all France?

${ }^{97}$ See Guy Coquille, La Coutume de Nivernais, Accompagnée D’ Extraits du Commentaire de Cette Coutume 81 (Henri Plon, 1864) ("The customs of the provinces of France, which are called customaries, are their civil and common law; and may be referred to as 'law' if they have been determined and put in writing, under the authorization of the King's commissioners, according to the consent of the people assembled in their three orders (called Estates).") See Gaudemet, Tendances at 182 (cited in note 80).

${ }^{98}$ See the discussion of DuMoulin's research as adding "luster to the French monarchy" in Donald R. Kelley, Foundations of Modern Historical Scholarship: Language, Law, and History in the French Renaissance 192 (Columbia, 1970).

so See generally Donald R. Kelley, Civil Science in the Renaissance: Jurisprudence in the French Manner, 2 Hist European Ideas 261, 269 (1981). Compare, for example François Hotman, Francogallia, Ralph Giesey, ed (Cambridge, 1972). Hotman, it should be noted, was a moderate exponent of unifled custom. " $\mathrm{He}$ is not content with the notion of a 'common customary law.' What he wants is the composition of a 'Code.' This latter is to be composed with the aid not only of the books of Justinian ... but also of books of philosophy ... and of experience." Gaudemet, Tendances at 186 (cited in note 80) (on Hotman's AntiTribonian).

${ }^{100}$ Agitation for unification of a 'droit coutumier' grew particularly strong in the 1660 s and 1670s. Gaudemet, Tendances at 187 (cited in note 80). The movement maintained its strength up to the French Revolution, and concordances of Roman and customary law of the eighteenth century eventually made their influence felt on Pothier, and through him on the Code Civil. Id at 189-90. See also Andre-Jean Arnaud, Les Origines Doctrinales du Code Civil Français, (Pinchon et Durand Auzias, 1969). 
tury France. Thus, for example, Charles Loyseau still assumed, in medieval fashion, that Roman law would generally serve as the suppletive body in the absence of attested custom:

Before applying the customs of Paris to other localities, one should examine Roman law. If Roman law contains a clear and final resolution of the point in issue, not repugnant to the general custom of France, even if the custom of Paris is different, it should be followed as the common law ... ${ }^{101}$

Note the phrase "not repugnant to the general custom of France" In it, we see something very closely akin to the Anglo-American idea of "unconstitutionality."

C. The Seventeenth Century on the Continent: Custom and Reason

In the seventeenth century, the DuMoulinian idea of "common customary law" began to influence the entire Continent. As in France, scholars produced treatises of customary law in response to the evidentiary crisis. ${ }^{102}$ It is in these treatises on general customary law, which often retained a "constitutionalist" flavor, that we begin to see, in full-blown form, the conflation of custom and reason, the roots of which this Article is intended to trace.

For these treatises were full of references to "natural law," "equity," and "reason." This is hardly surprising. "Customary common law," as I have indicated, hardly existed as such in most parts of Europe. What existed were records of isolated local customs, the products of earlier interrogations of local witnesses (or local estates) that had taken place long before. These records were full of gaps to be filled somehow-and had to be filled by some source that was not too offensive to the normative supremacy of custom. ${ }^{103}$ The lawyers did have some inoffensive options. They could look to the customs of neighboring localities; Roman law; or

${ }^{102}$ Guizzi, 37 Tijdschrift voor Rechtsgeschiedenis at 10 (cited in note 80) (quotiug Loyseau, Traité du Déquerpissement et Délaissement par Hypothéque in Ouevres 6 (Paris, 1640)).

102 See generally Luig, 1972 Juridicial Rev 193 (cited in note 80). Also important is the fact that, by the end of the century, as in France, university teaching of so-called "national" law hegan-teaching, that is, of a "customary common law" essentially invented by scholars. See Alfred de Curzon, L'Enseignement du Droit Français dans les Universités aux XVIIe et XVIIIe siècles, in 43 Nouvelle Revue Historique de Droit Français et Étranger 209, 21920 (1919).

${ }^{103}$ See Timbal, 52 La Coutume at 232 (cited in note 37), for a good discussion of the state of affairs in this period. 
some source such as the Custom of Paris, which was traditionally accorded a certain supremacy. ${ }^{104}$ But even when they looked to these sources, the lawyers maintained that they were only pursuing "equity" or "reason."10s In particular, they insisted that their use of Roman law was simply "written reason."

With the invocations of "reason" in these customary treatises, we have come to the crux of my tale. It is accordingly worth pausing to dwell on lawyers' motivations for these frequent appeals to "reason." The authors of customary treatises had, I suggest, two motivations for appealing to "reason." First, they were proposing to write about a non-existent subject matter, "customary common law." It was natural to resort to that "formidable non-entity, the Law of Nature," 107 by drawing upon the amorphous body of "natural law" thought to date back to the Stoics (and beyond). ${ }^{108}$ Second, these jurists had, as it were, a legitimation problem. It was, to the pre-eighteenth century mind, unlawful to make rules without consulting customary witnesses; and lawyers doing unlawful things need grand sources of authority. What these lawyers chose was the vague and magnificent authority of "reason."

In any event, the recourse to reason came easily to them. Medieval practice had long required that customs be reasonable. ${ }^{109} \mathrm{~A}$

104 See, for example, Francois de Boutaric, Les Institutes de l'Empereur Justinien conferées avec le Droit Français (Gaspard Henault et Jean-Francois Forest, 1754), for a survey of these traditional sources.

105 "[T] learned non-lawyer, see M. D. P. D. C. [Antoine Lacombe de Prezel], 2 Dictionnaire Portatif de Jurisprudence et de Pratique 150 (Leclerc, 1763) ("When the custom of the locality maintains silence, one has recourse to the Custom of Paris, to neighboring customs, or to the most general law and to that which seems most equitable.").

${ }^{100}$ The history of this view of Roman law in France is explored in Alejandro Guzmán, Ratio Scripta (Vittorio Klostermann, 1981). The tendency to view Roman law this way was also typical centuries earlier in the Middle Ages, among the first revivalists of the study of Roman law. See Ennio Cortese, Lex, Aequitas, Utrumque Ius nella Prima Civilistica, in "Lex et Iustitia" nell'Utrumque Ius: Radici; Antiche e Prospettive Attuali, 20 Utrumque Ius 95 (1989).

107 Jeremy Bentham, A Comment on the Commentaries, in J. H. Burns and H. L. A. Hart, eds, The Collected Works of Jeremy Bentham: A Comment on the Commentaries and A Fragment on Government 20 (London, 1977).

${ }^{108}$ For surveys, see Hans Welzel, Naturrecht und Materiale Gerechtigkeit (Vandenhoeck \& Ruprecht, 1962); Michael Crowe, The Changing Profile of the Natural Law (Martinus Nijhoff, 1977).

${ }^{109}$ The path toward the use of "reason" as a gap-filler was, I would like to emphasize, merely smoothed by the medieval tradition of requiring that proven customs be "reasonable." As discussed above, that tradition permitted courts only to deviate from custom, not-what is ultimately at issue-to supplement custom. A court that merely deviated could never claim the normative force of custom for its own activity. Nevertheless it is true that both traditions of invoking the "reasonable" reflected the same pressure on courts to innovate only while claiming the authority of "reason." 
jumble of Roman legal texts, moreover, had led medieval jurists to identify custom as a "secondary" form of natural law. Drawing upon this tradition, sixteenth-century lawyers found it comparatively easy to argue that "primary" natural law and "secondary" custom had a "common foundation ... in the dictates of the natural reason of man." "110 Furthermore, there was an Aristotelian tradition of arguing that long usage was the route to practical wisdom-the craftsmanlike "reason" celebrated in many Aristotelian texts. Those lawyers who worked in this tradition could easily assert that their craftsmanlike "reason" allowed them to extend custom without departing from the spirit of custom. ${ }^{111}$

All of these factors contributed to a tendency to resort to "reason" as a supplement to custom. In 1597, for example, Loyseau declared,

[O]ur customary laws . . . are so different and so confused that it is very difficult to extract from them a general and certain answer. [Accordingly,] the law must be married with the practice, usage with reason: in short, Roman law must be linked with our own. ${ }^{112}$

An inkling of this tendency could be already seen in mid-sixteenthcentury France when Nicolas Bohier wrote of a custom, in a striking phrase, that it "shows by natural law that all men are born free." 113 And, as the influence of DuMoulin spread, so also spread the DuMoulinian pattern outside of France. The tendency worked its way, most importantly, into the writings of the great natural

120 This important development is noted by Gierke, Natural Law and the Theory of Society at 38 (cited in note 23).

111 For the adoption of this Aristotelian notion by "topical". legal thinkers of the sixteenth century such as Donellus, Cantiuncula and Hegendorffinus, see Vincenzo Piano Mortari, Diritto Logica Metodo nel Secolo XVI 143-44 (Jovene, 1978). For a recent discussion of this notion in Aristotle from a Straussian point of view, see Stephen Salkever, Finding the Mean: Theory and Practice in Aristotelian Political Philosophy 105-60 (Princeton, 1990). But see also Paul O. Kristeller, Renaissance Thought and its Sources 45 (Columbia, 1979) (emphasis on importance of practical rather than speculative intellect to some extent properly humanist rather than Aristotelian). The tendency to regard the activity of jurists as "practical reason" is, of course, almost inevitable and appears in cultures more or less uninfluenced by Aristotle. For examples, see the Symposium, The Renaissance of Pragmatism in American Legal Thought, 63 S Cal L Rev 1569 (1990).

Also at work, undoubtedly, was the venerable tradition of describing custom as "altera natura," discussed in the works of Kelley (cited in note 5). Nevertheless, I do not emphasize this tradition, since it defined custom as something other than "prima natura."

11 Charles Loyseau, Traité du déguerpissement, in Howell A. Lloyd, The Political Thought of Charles Loyseau (1564-1627), 11 European Stud Rev 53, 53 (1981).

118 Kelley, Second Nature at 155 (cited in note 5). 
law thinkers of the lands east of seventeenth-century France. Grotius's general account of the law of Holland, for example, is a classic statement of the procedural history that led to the introduction of reason alongside custom:

21. Unwritten laws are old customs which similarly are either general ... or local ....

22. When no ... written laws [beschreven landrechten], privileges, by-laws or customs were found touching the matter in hand, the judges were from times of old admonished by oath to follow the path of reason according to their knowledge and discretion. But since the Roman laws . . . were considered by men of understanding to be full of wisdom and equity, these were first received as patterns of wisdom and equity and in course of time by custom as law. ${ }^{114}$

Here we have the classic pattern in its full glory. Judges were sworn to safeguard customary rights. But where customary rules were wanting, the judges had recourse to "reason." In typical seventeenth-century fashion, Grotius identified this "reason" with Roman law. 115 Moreover, this "reason" was the stuff of "men of understanding," full of "wisdom." In short, it is the craftsmanlike "reason" of the Aristotelian tradition.

Nor did the tendency die as the rationalizing seventeenth century progressed. Samuel Pufendorf, the other classic natural law thinker of the seventeenth century, maintained that the natural law which he so systematically elaborated was still suppletive. For Pufendorf, to be sure, custom had lost some of its claims. ${ }^{116}$ But even so, natural law remained suppletive:

[I]n all states natural laws support the civil law like a military reserve, so that when the latter has failed on some occurrence which altogether demands a decision in a human court of law, there is recourse to the laws of nature and to the analogy re-

114 Hugo Grotius, 1 The Jurisprudence of Holland 11 (Oxford, 1953). Grotius's work, which was not translated from the original Dutch until the mid-nineteenth century, was, I should hasten to add, unlikely to have been known to many American Revolutionaries.

115 The reason/Roman law thus applied has, however, itself nothing other than customary force. This, too, follows the medieval pattern.

116 For Pufendorf's continued acceptance of the traditional order, according to which custom trumped general law, see his description of the German legal order (drawn from Conring) in Severinus de Monzambano [Samuel Pufendorf], Über die Verfassung des deutschen Reiches 70-71 (Reimar Hobbing, 1922). This work, by contrast with Grotius's Jurisprudence of Holland (cited in note 114), was repeatedly translated in the eighteenth century. 
sulting from their comparison, whereby, however, that which is borrowed, as it were, from the law of nature takes on the force of civil law. ${ }^{117}$

Pufendorf's elegant statement represents the French tradition in its seventeenth-century maturity. ${ }^{118}$

In "reason," Continental lawyers found a partial solution to the evidentiary crisis. But it is important to recognize that it was only a partial solution. Reason and custom remained difficult to reconcile as a matter of logic. Lawyers could not always think of themselves as exercising Aristotelian craftsmanlike reason. In particular, revealed religion was a powerful force in their lives, which greatly complicated discussions of "reason." For many, though not all, jurists, "reason" had to be reconciled with religious revelation. ${ }^{119}$ Thus the jurists could associate "reason" with humanist concepts of "equity,"120 as well as with neo-scholastic concepts of justice, ${ }^{121}$ both of which grew out of ideas of revelation. ${ }^{122}$ The experience of religious revelation had little in common with craftsmanlike secular reason, and little in common with the experience of custom. Moreover, even when lawyers did have in mind craftsmanlike reason, they still had much to explain. In "extending" customary rules, in however craftsmanlike a fashion, lawyers were not consulting witnesses to determine the actual custom. A lawyer simply was not a local witness. ${ }^{123}$

${ }_{117}$ Samuel Pufendorf, 2 Elementorum Jurisprudentiae Universalis Libri Duo 161 (Oxford, 1931).

${ }^{118}$ For other examples of efforts to reconcile customary tradition with the law of nature, see George A. Struve, Syntagma Juris Feudalis 1-6 (Georg Henri Oehrling, 8th ed 1703); James Viscount of Stair, The Institution of the Law of Scotland, 73-95, D.M. Walker, ed (Yale, 1981).

119 Of course it is true that many, particularly early reformers, denied that reason and revelation could be reconciled. See, for example, the discussion of Melanchthon in Harold Berman and John Witte, The Transformation of Western Legal Philosophy in Lutheran Germany, 62 S Cal L Rev 1575, 1617-35 (1989).

${ }^{120}$ See Otto W. Krause, Naturrechtler des Sechzehnten Jahrhunderts (Peter Lang, 1982); Guido Kisch, Erasmus und die Jurisprudenz seiner Seit (Helbing \& Lichtenhahn, 1960); Guzmán, Ratio Scripta at 84 (cited in note 106).

${ }^{121}$ See Welzel, Naturrecht und Materiale Gerechtigkeit at 89 (cited in note 108).

122 For the humanist effort to reconcile reason and revelation-an effort alien to much of medieval tradition-see Guido Kisch, Claudius Cantiuncula: Ein Basler Jurist und Humanist des 16. Jahrhundert 47-56, 88 (Helbing \& Lichtenban, 1970). Much of this effort would presumably have been Ramist in nature. Compare text accompanying note 145 .

${ }^{123}$ Indeed, because the idea of reconciling custom and reason through a pragmatic conception of the latter is so attractive, I should emphasize how little it offers in explaining the sixteenth- and seventeenth-century history I trace. Two points need to be stressed. First, while "reason" could be discovered through the lived experience of custom, in early modern eyes "reason" had to be discovered by local witnesses, not by lawyers. This was precisely the 
Reconciling reason with custom presented one more jurisprudential difficulty. In the medieval order, custom trumped learned law. ${ }^{124}$ Where, in the new order, did this trumping tradition fit? There was real confusion over whether "reason" trumped custom or vice versa. Domat, the great French systematizer, conceded that the "Fundamental Laws"--the "usage général de France"-might trump such "Immutable Laws" as "Love God and love thy neighbor":

[L]aws have their Justice and Authority, only because of the relation which they bear to the order of society, and the spirit of those Fundamental laws; so that if it happen that the order of society, and the spirit of those fundamental laws, require that some of the immutable laws be restrained either by exceptions or by dispensations, they admit of those mitigations. ....125

Domat's confusion over how to treat natural law and customary law is noteworthy. As Continental lawyers reordered their jurisprudential assumptions in a world in which the historic procedures of the medieval customary regime were no longer to be found, they tended to commingle custom and reason.

\section{Early Seventeenth-Century England}

In the English world, too, the early seventeenth century saw developments closely parallel those on the Continent. There were, of course, pre-seventeenth-century developments of great importance in England. English seventeenth-century lawyers possessed a great body of relevant medieval learning, just as French seventeenth-century lawyers did. It is possible that English development paralleled Continental development far back into the Middle Ages. During the Middle Ages, the same grand tension between local custom and governmental law practice that played itself out on the Continent, played itself out in England. The leading historian of the common law summarizes the early development of the common law as follows: "Largely meaning only to enforce regularisation of

difficulty faced by DuMoulin and Rebuff. Second, while custom and reason can be reconciled through a pragmatic approach, what needs to be explained is why early modern lawyers needed to reconcile custom and reason. Lawyers would never have been driven to attempt a reconciliation of custom and reason if procedural pressures had not forced them to do so.

124 See text accompanying note 72 .

${ }^{225}$ Jean Domat, 1 The Civil Law in its Natural Order 60 (Charles C. Little and James Brown, 1850) (translated by William Strahan). 
[] customs, the king's court brought to an end the feudal jurisdictions which had applied them, and had to apply the customs itself." ${ }^{228}$ As on the Continent, the English princely courts tended, by a kind of hydraulic process, to draw disputes to themselves. As on the Continent, the princely courts committed themselves to "apply" custom. As on the Continent, the initial English practice was to determine custom through the consultation of local witnesses-especially as organized into juries. ${ }^{127}$ Indeed, English developments perhaps did not so much deviate from Continental developments, as anticipate them. ${ }^{128}$ The English royal courts extended their reach in the Middle Ages with greater success than did their Continental counterparts, and English lawyers very early on adopted, in some measure, the characteristic ideological claim of French lawyers-the claim, that is, to be applying only the common custom of the realm. ${ }^{12 \theta}$

At the same time, there were considerable differences between England and the Continent. The actual consultation of local witnesses ceased earlier in England than in France. ${ }^{130}$ Moreover, En-

${ }^{126}$ Milsom, Historical Foundations of the Common Law at 3 (cited in note 54).

127 Albert Kiralfy, $52 \mathrm{La}$ Coutume at 401 (cited in note 70). For the general acceptance of the common origin of the Anglo-Norman jury and continental custom-finding enquetes, see Poudret, $52 \mathrm{La}$ Coutume at 523 (cited in note 37). See also Cheyette, 78 Pol Sci Q at 362-90 (cited in note 63). For the procedural world of the very early common law, see also Milsom, Historical Foundations at 40-50 (cited in note 54).

13e It is far from easy to disentangle what was influence from what was independent invention. There is no doubt that England developed differently than the Continent in many ways. See Michael Lobban, Blackstone and the Science of Law, 30 Hist J 311, 317 (1987) ("[T]he Enghish had a peculiar problem, in so far as their common law was a welldeveloped system wholly outside the ius commune."). Nevertheless, as Professor van Caenegem has pointed out, the differences are too easy to exaggerate, and indeed were exaggerated by the nationalistic legal historians of the nineteenth century. Raoul $C$. van Caenegem, Procédure Civile Anglaise et Continentale: Problèmes de Périodisation (Résumé), in 1 La Formazione Storica del Diritto Moderno in Europa, 149, 151, 153-54 (cited in note 80 ). See also the valuable discussion of Gouron, Coutumes contre loi chez les premiers glossateurs at 127-29 (cited in note 37).

120 The description of royal law as such "custom of the realm" was at least as old as Glanvill. Baker, An Introduction to English Legal History at 15-16 (cited in note 35). References to the "law and custom of England" are yet older. See Kiralfy, 52 La Coutume at 381 (cited in note 70). For commercial practices and the law of common carriers as custom of the realm, see John H. Baker, Law Merchant and the Common Law before 1700, in The Legal Profession and the Common Law 363 (Hambledon, 1986). It is noteworthy that, on the Continent, one English practice-primogeniture-had become a byword for a custom so "notorious" as not to need proof. See note 68 .

130 English and French developments are compared in Cheyette, 78 Pol Sci $Q$ at 362-90 (cited in note 63). Unfortunately, this article exaggerates the extent to which French lawyers, like Enghish ones, had given up the practice of seeking out witnesses after the thirteenth century. As I have recounted above, Frencli lawyers were quite definite about the need to consult local witnesses well into the sixteenth century. Nevertheless, I am in general agreement with Cheyette's argument. 
glish jurists carefully differentiated "general custom" from "local custom," even in the twentieth century. ${ }^{131}$ The DuMoulinian argument that there was a single "general custom" embracing all localities could thus, perhaps, not always easily be made in the common law context, and litigants in the royal courts ordinarily did not confront anything as alien as Roman law. Perhaps for these reasons, and perhaps for others, there may have been little sign of the French pattern in the bulk of English writings before the seventeenth century ${ }^{\mathbf{1 3 2}}$ - though perhaps Fortescue and particularly St. German show the same pattern of argument that characterized their French contemporaries. ${ }^{\mathbf{1 3 3}}$

But, whatever the importance of earlier developments, a significant weight of English authority began to sound Continental in the early seventeenth century. As conflict over the extension of state power swelled in early seventeenth-century England, important English lawyers showed the same concern about the impossibility of "proving" custom as did their French counterparts. ${ }^{134}$

Indeed, many English lawyers hardly differed from Continental ones in their expressions of allegiance to the medieval tradition requiring the testimony of live witnesses. The civilian John Cowell stated,

It is enough for the profe of a custom by witness in the common law ... if two or more can agree, that they have heard their fathers say, that it was a custome all their time and that their fathers heard their fathers also say, that it was likewise a custome in their time. ${ }^{136}$

${ }^{131}$ For the famous example of Kentish succession, see Milsom, Historical Foundations at 11 (cited in note 54); and generally Kiralfy, Custom in Mediaeval English Law at 394 (cited in note 70 ).

${ }^{132}$ See Theodore F. T. Plucknett, A Concise History of the Common Law 277 (Lawyer's Co-op, 2d ed 1936) ("[I]t is clear that in the sixteenth century . . . custom had largely ceased to be a familiar notion to the common lawyers, who regarded it . . . as a troublesome and perhaps a dangerous anomaly which must be confined as strictly as possible within harmless limits."). I cannot state whetler the concerns I chart in tbe following text were new in the seventeenth century. If they were, however, we might reasonably hypothesize French influence as the cause.

133 For this argument (though without reference to the Contment), see Vossler, Studien at $187 \mathrm{n} 130$ (cited in note 24) ("To discern the law of God and the law of reason from the law positive is very hard.") (quoting St. German).

13، It may be the case tbat what the first part of the seventeenth century saw was an ideologically charged revival of what had been a neglected tradition of requiring local testimony.

${ }^{135}$ Kelley, The Human Measure at 100 (cited in note 5). For the attitude of English civilians on this point, see Daniel Coquillette, The Civilian Writers of Doctors' Commons, 
Cowell might be dismissed as a civilian outside the common-law mainstream. But in several cases in the early seventeenth century, common lawyers actually did determine custom in the historic way. For example, when Sir John Davies set out to break the customary land-holding patterns of Ireland in the first years of the seventeenth century, English officials, in this most famous instance of conflict over custom, began by determining the customary practices by interviewing local juries and witnesses, just as the French kings had done for centuries. ${ }^{136}$ Likewise, the famous case of Day $v$ Savadge held that, contrary to long-established practice, the custom of the city of London had to be proven by a jury where the city of London was itself a party:

[T] he Judges of every place are supposed to have knowledge of the laws of the place whereby they do judge, and to have customaries among them. And therefore in suits in their own Courts do determine them, as the Judges at the common law do in the King's Courts judge the general customs of the whole kingdom, being the common law. And so in London by special priviledge, they certifie also their customs of this nature, into the King's Bench, which other towns do not. But their customs, even those that are their local laws, are triable by jury, if they come to issue in the King's Courts. ${ }^{137}$

Or again, in the midst of the English Civil War, the Levellers, in a last burst of medievalizing ideology, argued for a time that juries retained their law-finding character. ${ }^{138}$ These examples testify to the lasting strength (or perhaps the reviving strength) of the medieval notion that law was properly custom, and that custom was

London: Three Centuries of Juristic Innovation in Comparative, Commercial and International Law 37 (Duncker \& Humblot, 1988).

136 See Hans Pawlisch, Sir John Davies and the Conquest of Ireland: A Study in Legal Imperialism 69-70 (Cambridge, 1985). In the event, the English, following established medieval doctrine (see note 70 and accompanying text), determined that the Irish customs in question were not "reasonable." It is remarkable that the English felt compelled to stand by medieval doctrine with regard to the interviewing of local witnesses even in a case in which they were to abohish the customs in question.

${ }^{237}$ Day v Savadge, 80 ER 235, 236, Hob 85, 87 (James I 1615). For another bow to custom, compare the invocation of the maxim "potentior est vulgaris consuetudo quam regalis concessio" ("popular custom is more powerful than royal concession") in The City of London's Case, 77 ER 658, 662, 8 Co Rep 121, 125 (James I 1610). The City of London's Case is quoted and discussed in Julius Goebel, 1 Holmes Devise History of the Supreme Court of the United States: Antecedents and Beginnings to 180159 n 34 (McMillam, 1971).

${ }^{136}$ Thomas Andrew Green, Verdict According to Conscience: Perspectives on the English Criminal Trial Jury, 1200-1800 160-61 \& n 24 (Chicago, 1985). 
properly to be proven by the testimony of witnesses. ${ }^{139}$ Like their French contemporaries Fortin and Loysel, ${ }^{140}$ early seventeenthcentury English lawyers had become conscious of the procedures historically associated with the jurisprudence of custom.

Yet, even if memories of the medieval legitimating procedure revived in the early seventeenth century, that procedure, in actual practice, was long dead. In England, if not in Ireland, the "custom of the realm" was not ordinarily determined by consulting "two or more who can agree, that they have heard their fathers say that it was a custome." The procedural norm and the procedural practice had diverged in England just as they had diverged on the Continent. English lawyers, like Continental ones, accordingly had much to explain. Indeed, the English legal literature of the sixteenth and seventeenth centuries is rife with passages that seem to cry out for some mild variety of deconstructive reading, so patently conscious were their authors of the oddity of accepting the basic norm of custom without consulting local witnesses. Thomas Hedley's 1610 address to Parliament exemplified the English lawyers' pattern of thought:

[T] ]he common law is a reasonable usage, throughout the whole realm, approved time out of mind in the king's courts of record which have jurisdiction over the whole kingdom, to be good and profitable for the commonwealth. But here because I make custom a part in my definition of the common law, I would not be mistaken, as though I meant to confound the common law with custom, which differ as much as artificial reason and bare precedents. Customs are confined to certain and particular places, triable by the country, but their reasonableness or unreasonableness by the judges, to be taken strictly according to letter and precedent, and therefore admits small discourse of art or wit; whereas the common law is extended by equity, that whatsoever falleth under the same reason will be found the same law. ${ }^{141}$

Only the hardy will attempt to come up with a clear analytical account of how custom, reason, equity, and common law, as described in such passages, differ in practice. What matters, for my

139 Nor is this surprising: this was an age when English historical thinking, like French, was developing rapidly. See generally, J.G.A. Pocock, The Ancient Constitution and the Feudal Law (Camhridge, 2d ed 1990).

${ }^{240}$ See text accompanying notes 87 and 88 .

141 Speech of Thomas Hedley to Parliament in 1610, in Pocock, The Ancient Constitution and the Feudal Law at 272-73 (cited in note 139). 
purposes, is not the clarity of Hedley's ideas of the common law, but their motivation; and their motivation was a concern with proof-or rather lack of proof. Hedley still thought of custom as provable through local testimony- "tria[l] by the country." But, at the same time, he wished to claim for the common law the status of custom-a proposition of almost baroque impossibility.

In this, Hedley's problem was, generally speaking, no different from DuMoulin's. How was the "general custom of the realm" to be "extended" when no record existed of a customary solution and no local witnesses could be consulted? Hedley's answer was, in essence, the same as that given on the Continent: the "general custom" was to be "extended" through "equity" and "reason." English lawyers had begun to develop an association of common law with the law of reason comparable to that of Nicolas Bohier or Pierre Rebuffi sixty years earlier.

Hedley's approach was typical. For example, Serjeant Ashley declared in 1628 that the jus gentium "ever serves for supply in the defect of the common law, when ordinary proceedings cannot be had." "142 There indeed was the rub: of course, ordinary proceedings could almost never be had. More important is Sir Edward Coke, by far the seventeenth-century lawyer most influential on the American Revolutionaries. Coke accepted many Continental doctrines of custom that had entered medieval English legal literature. ${ }^{143}$ None of these doctrines saved Coke from the necessity of explaining why traditional forms of customary proof were not required to establish "common custom." Thus he wrote: "[T]he customs and courses of every of the King's Courts are as a law, and the common law, for the universality thereof, doth take notice of them; and it is not necessary to allege in pleading any usage or

${ }^{142}$ See Brian Levack, The Formation of the British State: England, Scotland and the Union, 1603-1707 80 (Oxford, 1987). See also Bacon, De Augmentis Scientiarum, Bk VIII, Ch 3, Aphorism 11 (Collier, 1900) ("In omitted cases, the rule of law is to be drawn from cases similar to them, but with caution and judgment; wherein the following rules are to be observed: Let reason be esteemed prolific and custom barren. Custom must not make cases.").

${ }^{163}$ For example, "consuetudo privat communem legem" ("custom trumps common law"). See John H. Baiker and S. F. C. Milsom, Sources of English Legal History: Private Law to 1750598 (Butterworths, 1986). See generally J. H. Thomas, ed, I Systematic Arrangement of Lord Coke's First Institute of the Laws of England Matthew Hale's Analysis 27-31 (Alexander Towar, 1836). English tradition could be quite as cavalier with the Code of Justinian as Obertus de Orto (see note 37) had been. See id at 27 ("longaevi enim temporis usus et consuetudinis non est vilis autloritas") ("long-standing usage and custom are of no mean authority")) (quoting Bracton). Like Obertus's statement, this daringly altered C. 8, $52,2$. 
prescription to warrant the same."144 The question Coke addressed, whether law could claim, as all legitimate law must, the force of custom, without the ordinary customary forms of proof, was the governing question for lawyers all over Europe. What kind of legitimate world could they have without proper "pleading [of] usage and prescription," without going down to the manor or village to ask the inhabitants what was right? Coke was only typical in his concern with proof problems.

Moreover, Coke was typical in his solutions. This emerges quite clearly in his famous 1609 decision in Calvin's Case. In a well-known passage from that case in which he developed his doctrine of artificial reason, ${ }^{145}$ Coke made it quite clear that his problem was the same as that of Continental lawyers. He quoted standard Continental doctrine on the unprovided-for case:

[It is argued that] for want of an express text of law "in terminis terminantibus," and of examples and precedents in like cases (as was objected by some), we are driven to determine the question by natural reason: for it was said, "si cessit lex scripta, id custodiri oportet, quod moribus et consuetudine inductum est; et si qua in re hoc defecerit, recurrendum est ad rationem." ["in default of written law, one should abide by that which has been introduced by mores and custom; and if

${ }^{144}$ Lane's Case, $76 \mathrm{ER} 423,424,2$ Co Rep 16, 16 (Elizabeth I 1596) (footnotes omitted). Coke also declared: "in hiis, quae de jure communi omnibus conceduntur consuetudo alicuius patriae vel loci non est alleganda" ("with respect to those things which are generally recognized by common law, evidence of the custom of a given region or place is not to be offered"). The Case of Monopolies, 77 ER 1260, 1261, 11 Co Rep 84, 85 (Elizabeth I 1603). Coke's statement is quoted and misinterpreted by Christopher Hill, Intellectual Origins of the English Revolution 251 \& $\mathrm{n} 9$ (Oxford, 1965). "Non est alleganda" does not mean, as Hill beheves, "is not to be alleged," but rather "evidence need not be offered."

The last-quoted phrase raises a further question. Is Coke offering the established Continental doctrine of "notorious custom," typically used to describe English affairs? See note 68. It seems possible. But, of course, even regarding the common law as "notorious" custom would not have solved Coke's problem, since it offered no solution to the problem of the unprovided-for case.

${ }^{145}$ For the importance of this doctrine, see, for example, William Holdsworth, 5 A History of English Law 478-84 (Methuen, 3d ed 1966).

The concept of "artificial logic" or "artificial reason" was not new to legal writing when it appeared in Coke's work. Abraham Fraunce, an importer of Ramist logic and the author of The Lawiers Logike (1588), had already proposed these concepts in the legal context some twenty years earlier. See the discussion in Ralph Pomeroy, The Ramist as FallacyHunter: Abraham Fraunce and The Lawiers Logike, 40 Renaissance Q 224, 237-38 (1987). For the importance of the hterature exploring Ramist influence in England during this period, see Knut Wolfgang Nörr, The European Side of the English Law: A Few Comments from a Continental Historian, in Knot Wolfgang Norr and Helmut Coing, eds, Englische und Kontinentale Rechtsgeschichte: ein Forschungsprojekt 19 (Duncker \& Humblot, 1985). 
this is insufficient in any respect, one should recur to reason."] But that receiveth a threefold answer. First, that there is no such rule in the common or civil law: but the true rule of the civil law is, "lex scripta si cesset, id custodiri oportet quod moribus et consuetudine inductum est; et si qua in re hoc defecerit, tunc id quod proximum et consequens ei est; et si id non appareat, tunc jus, quo urbs Romana utitur, servari oportet." ["in default of written law, one should abide by that which has been introduced by mores and custom; and if this is insufficient in any respect, one should draw upon that which is nearest and most related to it; and if that fails, one should observe the law which the city of Rome uses."] Secondly, if the said imaginative rule be rightly and legally understood, it may stand for truth; for if you intend ratio [reason] for the legal and profound reason of such, as by diligent study and long experience and observation are so learned in the laws of this realm, as out of the reason of the same they can rule the case in question, in that sense the said rule is true: but if it be intended of the reason of the wisest man that professeth not the laws of England, then (I say) the rule is absurd and dangerous, for "cuilibet in suâ arte perito est credendum, et quod quisque norit in hoc se exerceat. Et omnes prudentes illa admittere solent, quae probantur iis, qui in suâ arte bene versati sunt." Arist. 1. Topicorum, cap. 6. ["he who is learned in his craft is to be believed, and each should expend his labor in that with which he is familiar. And all wise persons are in the habit of believing the testimony of those who are well versed in their craft."] Thirdly, there be multitudes of examples, precedents, judgments, and resolutions in the laws of England, the true and unstrained reason whereof doth decide this question. ${ }^{146}$

Coke here offers a theory little different from those current a generation earlier in France. Like Pierre Rebuff, Coke speaks of extending customs to "similia." And like both Rebuffi and DuMoulin, Coke takes jurists as his witnesses, "not," as DuMoulin had written, "private persons, but leading men."147 Finally, like Rebuffi, Grotius, and many others, Coke defends his customary witness-like jurists by invoking Aristotle and the concept of

${ }^{140}$ Calvin's Case (James I 1608), in T. B. Howell, ed, 2 A Complete Collection of State Trials and Proceedings for High Treason and Other Crimes and Misdemeanors from the Earliest Period to the Year 1783 607, 641 (T. C. Hansard, 1816) (footnotes omitted).

${ }^{147} \mathrm{Du}$ Moulin, Oratio at 692 (cited in note 89). 
craftsmanlike "reason." Coke's famous, elusive doctrine represented, to be sure, an uncommonly thoughtful solution to the crisis of proof I have described. But in essence Coke was tracing paths already well-trodden.

And, like Continental contemporaries and predecessors, ${ }^{148}$ Coke had produced, in the process, a body of thought that could have been calculated to baffle later readers-a body of thought that promiscuously embraced both custom and reason without any superficially apparent grounds.

The same pattern continued over the subsequent century, to include the other seventeenth-century English lawyer influential on American thought: Sir Matthew Hale. Hale, who was notable for his insistence upon the fundamentally oral character of English law, ${ }^{149}$ showed the same historic faint embarrassment as did preWar lawyers. This showed particularly in his contributions to the great common-law legal theory of the early modern period, the mysterious "declaratory theory of precedent," characterized by the formula, prior decisions constitute evidence of what the law is:150

[T] he decisions of courts of justice . . . have a great weight and authority in expounding, declaring and publishing what the law of this kingdom is, especially when such decisions hold a consonancy and congruity with resolutions and decisions of former times, and though such decisions are less than a law, yet they are a greater evidence thereof than the opinion of any private persons, as such, whatsoever. ${ }^{151}$

Much as this theory of precedent has puzzled scholars, it need not puzzle anyone familiar with the history I have traced. The "private persons" Hale declared to be unnecessary were the villagers who, in earlier centuries, had served as the repositories of common custom. In Hale's insistence that those villagers were not needed, we

148 Indeed, Coke was also like his English contemporaries. Coke's colleague and critic Ellesmere, too, insisted that Continental and English law simply did not differ on the supremacy of custom. Calvin's Case, in 2 State Trials and Proceedings at 670 (cited in note 146) ("wee concurre with the Ciuile Lawe"). But Ellesmere insisted on accepting the new model jurisprudence: the "reason" to be used in defect of custom was no different from the reason to be used in any other situation. See the discussion in Gray, Reason, Authority, and Imagination at 30-31 (cited in note 19).

149 Kelley, Human Measure at 166 (cited in note 5).

${ }^{180}$ For an example of the "declaratory theory," see Rupert Cross, Precedent in English Law 24 (Oxford, 3d ed 1977). This "declaratory theory," which has vanished from the American literature, still appears sporadically in English opinions. For recent English examples, see Reginald W. M. Dias, Jurisprudence 151 (Butterworths, 5th ed 1985).

${ }^{151}$ Matthew Hale, The History of the Common Law of England 45 (Chicago, 1971). 
hear a lawyer protesting too much. Like Rebuffi and DuMoulin, Hale is eager to show why the decisions of lawyers-or, in this case, judges-serve adequately in a customary system. In his conception, judges are simply a species of customary witness; and precedents are simply the testimony of a species of customary witness.

It is beyond my command of the sources to say whether the English, in facing the common western dilemmas, borrowed their attempted solutions from the French, or invented them independently. The question may be ultimately unanswerable, since borrowers of nationalist ideologies always disguise, or conveniently forget, their sources. ${ }^{152}$ Nevertheless, whatever their sources, the English sounded like the French, not only in their theory of the common law, but in their tendency to mix legal theory with constitutionalism and ideas of popular will. One can quote Thomas Wentworth-"The common laws are but custom, and wee claime our liberties by the same title as we do our estates, by custome-"1ss or indeed, John Davies, in whose statements Pocock saw only an "unconscious kinship" with the writings of Hotman:

[T] he Common Law of England is nothing else but the Common Custome of the Realm[,]

[and] a Custome taketh beginning and groweth to perfection in this manner: When a reasonable act once done is found to be good and beneficiall to the people, and agreeable to their nature and disposition, then do they use it and practise it again and again, and so by often iteration and multiplication of the act it becometh a Custome .... ${ }^{154}$

And whatever their sources, it is clear, I suggest, that the seventeenth-century English were dealing with precisely the same evidentiary crisis as were the French. By the end of the seventeenth century, the English had produced a body of literature identifiably part of a grand European jurisprudential tradition, in which, responsive to the evidentiary crisis of custom, lawyers had learned to mix custom, reason, and the will of the people-a tradition that united Coke and Hale with Domat, Grotius and Pufendorf.

\footnotetext{
${ }^{162}$ For controversy over this question, see Pocock, The Ancient Constitution and the Feudal Law at 280-88 (cited in note 139).

182 See McIlwain, Constitutionalism, Ancient and Modern at 113 (cited in note 15).

154 Pocock, The Ancient Constitution and the Feudal Law at 32-33 (cited in note 139) (quoting John Davies).
} 


\section{The Eighteenth Century: "Mingling" Custom and REASON IN ENGLAND aNd ON THE Continent}

It is in this hopeless seventeenth-century love of unprovable custom that we can see the roots of eighteenth-century "mingling" jurisprudence. By the eighteenth century, the problems of proof that motivated the authors of the sixteenth and seventeenth centuries seem to have been forgotten. With Louis XIV's abolition of the old practice of interrogating local witnesses in $1667^{185}$-and, more broadly, the great surge of intellectual innovation at the end of the seventeenth century ${ }^{158}$ - the tradition of customary proof that had been present in seventeenth-century minds was, as far as one can judge, generally lost from sight. ${ }^{15 z}$

But if problems of proof had been forgotten, a pattern of mingling reason and custom had been set-a pattern ready to impress itself upon the minds of readers of the classic legal literature of the seventeenth century. Moreover, it was a pattern ready to be misinterpreted in a variety of ways. By the eighteenth century, the concept of "reason" had profoundly changed. The deductive tradition associated with Descartes and Grotius had established itself powerfully. Accordingly, when eighteenth-century lawyers spoke of "reason," they most often meant, not craftsmanlike reason, nor revealed truth, but the activity of reasoning from first principles. Recall the quote of Louis Boullenois at the beginning of this Article. Boullenois, still attempting in DuMoulinian fashion to produce a common custumal for all France, took Descartes as his guide:

I recalled the method practiced once upon a time by $M$. Descartes to arrive at the philosophical verities he sought; and I persuaded myself that the Jurist could do the same in order to discover the verities of Justice .... . If one were to compare the various customs [of France], one would be in a position to form a Plan of Universal Jurisprudence . . . .158

\footnotetext{
${ }^{155}$ For the abolition, see, for example, Filhol, $17 \mathrm{La}$ Preuve at 370-71 (cited in note 46). 1990).

${ }^{186}$ See Paul Hazard, The European Mind: The Critical Years, 1680-1715 (Fordham,

157 For helpful observations on the eighteenth-century end of the tradition I bave described, distinguishing intriguingly among Prussian, Austrian and Italian strains, see Giovanni Tarello, La crisi del diritto comune nel secolo XVIII: un problema storiografico, in Danilo Segoloni, ed, Il Diritto Comune e la Tradizione Giuridica Europea: Atti del Convegno di Studi in Onore di Giuseppe Ermini 433-41 (Libreria Universitaria, 1980).

${ }_{158}$ Boullenois, Dissertations sur des Questions qui Naissent de la Contrariété des Loix et des Coutumes at xiv, xxii (cited in note 2). On Boullenois, see Abrégé de la Vie de Maître Louis Boullenois, Avocat, in Louis Boullenois, 1 Traité de la Personnalité et de la Réalité des Loix, Coutumes ou Statuts xvi-xxiv (Guillaume Desprez, 1766); 5 Biographie Univer-
} 
This was a strange marriage indeed of Descartes and DuMoulin. Nor was Boullenois alone. François Bourjon, another eighteenthcentury custumal compiler, was slightly more faithful to sixteenthcentury tradition. But he too betrayed the influence of the new ideas of reason. Describing, in 1747, the need to "fill the voids in the body of custom," Bourjon methodically attempted to "reduce custom and its assumptions to its principles and decisions . . . . [T] hose principles have, by their nature, a majestic simplicity, and if custom were not reduced to those principles it would be impossible to arrive at the general point of view which is the soul of jurisprudence . . . ."159 Lawyers like Boullenois and Bourjon mingled custom and deductive reason, not because of any deep impulse of jurisprudential logic but because they were still working in a sixteenth-century tradition of customary law scholarship in an age when "reason" had assumed new connotations.

Boullenois and Bourjon were, it should be said, not typical of France. In the bulk of French legal literature there was relatively little minghing of custom and reason. The pattern is noticeably absent in the writings of Montesquieu, as well as in the work of deductive natural law text-writers like Burlamaqui and Vattel. ${ }^{160}$ But the same was not true in England, in Germany, or in colonial America. In those countries, the mingling pattern continued, just as it did in the writings of Boullenois and Bourjon.

In England, the pattern was particularly evident in Blackstone's Commentaries, themselves an English product of the Europe-wide movement to produce evidence of customary law in treatise form. ${ }^{161}$ Scholars have long been baffled by Blackstone's use of

selle (Michaud) Ancienne et Moderne 247-48 (Madame C. Desplaces, 2d ed 1854) (Boullenois's capsule biographic entry in an undated collection).

${ }^{169}$ Francois Bourjon, Dissertation sur l'Union du Droit Commun de la France avec la Coutume de Paris, in Francois Bourjon, 1 Le Droit Commun de la France et la Coutume de Paris Réduits en Principes (1747) (unpaginated dissertation). The quoted passages are taken from an eight-step method laid out by Bourjon which was to result in the exposition of the "natural order" of French customs as "M. Domat has done for Roman law."

${ }^{100}$ In particular, of course, they began to emphasize reason to the exclusion of any other value. The ultimate result, hy the early nineteenth century, was a legitimating doctrine which Luhmann attributes to all liberal societies, but which was surely specifically French during that period. Luhmann refers to Guizot: "The core of all classical procedural doctrine is the reference to truth or justice as a goal. [As Guizot said,] 'All of the elements of the pohitical machine must be designed, on the one hand, to extract from society all of the reason, justice, truth it possesses, in order to apply [these virtues] to its government . . . ." Luhmann, Legitimation durch Verfahren at 18 (cited in note 49). To the (perhaps limited) extent that Luhmann is discussing the use of "reason" as a legitimating concept, the tale, I hope I have shown, is much more complex than Luhmann's readers might suppose.

${ }^{101}$ For Blackstone's place in international context, see John Cairns, Blackstone, an English Institutist: Legal Literature and the Rise of the Nation State, 4 Oxford J Legal Stud 
the concept "natural law"; 162 by his discussion of the relation of "custom," "precedent" and "reason"; ${ }^{163}$ " and by his classic statement of the declaratory theory of precedent. ${ }^{164}$ The uncertainty among Blackstone scholars reflects uncertainty in the tradition to which Blackstone belonged. This uncertainty was inevitable in a tradition which used a fundamentally medieval vocabulary of custom in a world from which medieval proof practices had vanished, and in which "reason" had entered the realm of first principles.

The same is arguably true of the notorious problem of whether Blackstone did or did not accept the idea that statutes could be "unconstitutional."165 Like Domat and other Continental lawyers, Blackstone still believed, in some measure, in the medieval idea of "trumping." But he was unsure which, if any, of the types of law

318 (1984); Alan Watson, The Structure of Blackstone's Commentaries, 97 Yale L J 795 (1988).

${ }^{182}$ For recent examples of the venerable tendency to minimize Blackstone's references to natural law, see Lobban, 30 Hist J at 326 (cited in note 128) ("Although Blackstone asserted the key notion that all laws agamst reason are void, he used the idea in Coke's sense that one could not assign the reason of any particular law, since it was lost in the mists of time. It was not the reason of individuals that could criticise law, but the authority of ages."); Grey, 30 Stan L Rev at 859-60 (cited in note 70) ("Blackstone's popularity can be attributed to his smooth transformation of the crabbed particularities of the English law into the abstract and universal language demanded by the intellectual fashions of the Enhightenment. His theoretical bow to the ultimate supremacy of natural law was dictated by the same fashions .....").

Others have asserted that natural law played a central role in Blackstone's thought, but these latter scholars have not agreed on just what that central role might have been. See John Finnis, Blackstone's Theoretical Intentions, 12 Natural L F 163 (1967); H.L.A. Hart, Blackstone's Use of the Law of Nature, 1956 Butterworth's S African L Rev 169.

${ }^{163}$ William Blackstone, 1 Commentaries on the Law of England 69-70 (Chicago, 1979). See Lieberman, Province of Legislation at 44 (cited in note 16).

${ }_{164}$ Blackstone, 1 Commentaries at 68-69 (cited in note 163) ("As to general customs, or the common law, properly so called; this is that law, by which proceedings and determinations in the king's ordinary courts of justice are guided and directed. . . [H] customs or maxims to be known, and by whom is their validity to be determined? The answer is, by the judges in the several courts of justice. They are the depositary of the laws; the living oracles, who must decide in all cases of doubt, and who are bound by an oath to decide according to the law of the land.... [T]hese judicial decisions are the principal and most authoritative evidence, that can be given ... of the common law.").

${ }^{185}$ See one of Blackstone's passages that has puzzled many historians of parhiamentary supremacy:

"[A]cts of parhament that are impossible to be performed are of no validity; and if there arise out of them collaterally any absurd consequences, manifestly contradictory to common reason, they are, with regard to those collateral consequences, void. . . . But if the parliament will positively enact a thing to be done which is unreasonable, I know of no power that can control it ...."

Blackstone, 1 Commentaries at 91 (cited in note 163). This facially self-contradictory passage was typical of the later eighteenth century, when the "trumping" tradition still survived in a legal environment alien to medieval legal assumptions. 
he knew "trumped" the others. To be sure, Blackstone was a thoughtful lawyer, who (like Hale before him) brought great agility to the task of reconciling custom and reason. ${ }^{186}$ Nevertheless, it was a task he faced only because he, like his Continental contemporaries, faced a tradition that mixed terminology about "reason" and "custom," none of which had clear meaning in the eighteenthcentury world.

The seventeenth-century tradition found a readership as well in the provincial corner of the eighteenth century world that was America. As the Revolution approached, American colonists read, of course, much that did not grow out of the tradition I have described-for example, Montesquieu, and the deductive treatisewriters Vattel and Burlamaqui. ${ }^{167}$ But they also read much seventeenth- and eighteenth-century literature that embodied the mix of custom and reason $I$ have traced: for example, Pufendorf, Coke, Hale, and Blackstone. As a result, when the colonists applied the deductive idea of reason they learned from their eighteenth-century readings, they applied it within the mingling tradition of the seventeenth century. The result was the strange body of thought of which I began by surveying, a body of thought much in the spirit of Boullenois and Bourjon. It was this mix of seventeenth- and eighteenth-century thought that informed Roger Sherman's declaration that "[t]he Colonies adopt the common Law, not as the common Law, but as the highest Reason," and that informed Otis's frantic efforts to reconcile common law and natural law. ${ }^{188}$ It was this confused thought that led five states to preface their constitutions with "a jarring but exciting combination of . . . universal principles with a motley collection of common law procedures . . . " "168 In this typically early modern thought, embodying as it did a medieval vocabulary, reworked for use in a seventeenth-century world, lay the roots of chaotic American legal thought.

\section{CONCLUSION}

What had happened over the course of the several centuries I have discussed? From the beginning, lawyers in governmental

${ }^{168}$ I refer again to the discussions of Lieberman, Province of Legislation at $44-45$ (cited in note 16); and Postema, Some Roots of our Notion of Precedent at 152-53 (cited in note 19).

${ }^{167}$ For the dating of the rise of natural law thought in America, see Wright, American Interpretations of Natural Law at 36-61 (cited in note 11).

${ }^{168}$ See Wood, Creation of the American Republic, 1776-1787 at 9 (cited in note 15).

${ }^{160}$ Id at 271. 
courts had accepted the basic norm of custom and embraced a legitimating procedure geared to that basic norm: the consultation of local witnesses. That procedure, however, was difficult to apply from the outset. With the collapse of local society, and the explosion of governmental jurisdiction in the sixteenth century, it became clear that proper legitimating procedure was not being applied, and indeed could not be applied, in a preponderant part of European litigation. Nevertheless, lawyers stood by the basic norm of custom. Conscious of the impossibility of applying the old procedure, however, they substituted new law-finding procedures. In particular, they "extended" recorded customs to "similar cases" and applied "reason" and "natural law" to fill gaps in the customary system.

The result was a jurisprudence that constituted a Europe-wide pretense: the pretense that law was still fundamentally customary, even though no local witness had been consulted for generations. In this literature of legal pretense, custom and reason were mingled, not because any inner jurisprudential logic linked them, but because of the requirements of the pretense itself. This literature of legal pretense lingered in the eighteenth century long after the procedural problems that had given rise to it were forgotten, and long after the concept of "reason" had entered upon highly deductivist paths of development. Eighteenth-century lawyers read the old literature, though they did not perfectly understand it. As a result, eighteenth-century authors repeated the century-old patterns of mingling custom and reason, without any evident memory of the procedural reasons for those patterns.

Jurisprudential thinking, in this history, did not simply arise from, nor did it accommodate itself easily to, the institutional ordering. Jurisprudential thinking did not even legitimate institutional ordering in any very satisfactory way. Rather, the jurisprudential pattern I have traced arose because there was no easy way for lawyers to justify their institutions. It arose, as it were, not in the interstices of procedure, but in the painful gap between legitimative needs and procedural impossibilities. And when it arose, it took the form of an improvisatory hash of ideas, which no amount of ingenious argument will ever turn into a body of logically reasoned jurisprudence.

As for the legal historiography of the American Revolution: the tale I have told suggests what was perhaps already obvious enough. There is little point in trying to identify the underlying logic of American legal thinking in the revolutionary era. That le- 
gal thinking was a confused mélange, the product of centuries of jurisprudential improvisation in the face of centuries of complex institutional change. Accordingly, there is little hope of drawing clear guidelines for concepts such as "constitutionality" or "rights" from the legal world of the eighteenth century. To be sure, it is possible to some extent to trace the idea of "unconstitutionality" to the "trumping" character of custom in later medieval Europe; and the oath required of American judges can be linked to the oath required of ius commune judges centuries earlier. But that does not show what Americans believed "unconstitutionality" to entail. On the contrary, American presuppositions about constitution, custom, common law and natural law, and their mutual "trumping" power, were unconquerably vague, ripped as they were from procedural context.

Studies that purport to explain the Founders' conception of the Constitution ${ }^{170}$ are thus doomed to mislead. Such studies perhaps deserve the same disrepute that has become the lot of studies of original intent of the drafters of this or that eighteenth-century document. ${ }^{171}$ If we cannot understand what the revolutionary era lawyers meant by "constitution" or "rights," still less can we identify any single deep jurisprudential tendency behind their writings. The Revolution was not "about" reason; nor was it "about" customary rights. We must accept the fact that the American Revolution, like most such upheavals, was inspired by a poorly-digested

170 For examples of studies of the general jurisprudential assumptions of the revolutionary era, see Grey, 30 Stan L Rev at 843 (cited in note 70); Grey, The Original Understanding and the Unwritten Constitution, in Neil York, ed, Toward a More Perfect Union: Six Essays on the Constitution 145 (Brigham Young, 1988); Suzanna Sherry, The Founders' Unwritten Constitution, $54 \mathrm{U}$ Chi L Rev 1127 (1987). Also in the same tradition, but less susceptible to my objections here, is Jefferson Powell, The Original Understanding of Original Intent, 98 Harv L Rev 885 (1985).

171 For objections to original intent scholarship, see, for example, the essays collected in Jack Rakove, Interpreting the Constitution: The Debate Over Original Intent (Northeastern, 1990); and William Nelson, 1966: Constitutional History, in William Nelson and John P. Reid, eds, The Literature of American Legal History 95, 118-24 (Oceana, 1985).

The most interesting examples of the genre are not necessarily the best known. For noteworthy studies of original intent, see Harold Chesnin and Geoffrey Hazard, Chancery Procedure and the Seventh Amendment: Jury Trial of Issues in Equity Cases Before 1791, 83 Yale L J 999 (1974), and the response by John Langbein, Fact Finding in the English Court of Chancery: A Rebuttal, 83 Yale L J 1620 (1974). Prohably the most imfluential study of original intent ever published in the United States was Cliarles Warren, New Light on the History of the Federal Judiciary Act of 1789, 37 Harv L Rev 49 (1923). For the influence of Warren's article, see Fred R. Shapiro, The Most-Cited Law Review Articles iv (W. Hein, 1987); and Erie R. Co. v Tompkins, 304 US 64, 73 n 5 (1938). 
farrago of ideas, without inner logic-by a confused body of law that will never provide us with any single authoritative doctrinal legacy. 